\title{
The Challenges of Representing Rural Migrant Workers in China: Factors Influencing the Goals and Strategies of Labour NGOs in Beijing, Tianjin and Yunnan Province
}

by

\author{
Ao Zhou \\ A thesis \\ submitted to the Victoria University of Wellington \\ in fulfilment of the requirements for the degree of \\ Master of Commerce \\ in Human Resource Management and Industrial Relations
}

Victoria University of Wellington

2020 


\begin{abstract}
Labour NGOs operating in mainland China have played the role of de facto representatives of rural migrant workers since their emergence in the 1990s. After their rapid development for almost two decades, the introduction of the Overseas NGOs Management Law in 2017 restricted all foreign sponsors of labour NGOs, which were their main funding source. This has greatly influenced their goals and strategic choices when representing migrant workers. However, due to increased political sensitivity, few studies have explored the current challenges they face since the law was implemented.
\end{abstract}

This study identifies both the pre-2017 and post-2017 goals and strategies of labour NGOs operating in Beijing, Tianjin and Yunnan Province. It also analyses six factors affecting the NGOs' goals and strategic choices after 2017. A case study research method is used to draw on 15 in-depth, semi-structured interviews with the founders, managers and staff working in 10 different labour NGOs in the three regions. The research results challenge the applicability of four main social movement theories learnt from the west - Resource Mobilisation (RM), Political Opportunity (PO), Transnational Advocacy Networks (TAN) and Stakeholder theory - to explain Chinese grassroots labour movements conducted by labour NGOs. The results also show that labour NGOs are experiencing a significant decline after the introduction of the Overseas NGOs Management Law, but have not withdrawn from the historical stage. Many NGOs are adjusting their goals and strategies to adapt to the changed political climate and survive. Finally, this study advocates the development of a new social movement theory which could accurately guide grassroots labour movements in the context of China. 


\section{Acknowledgements}

I would like to express my deepest gratitude to my supervisor, Dr Stephen Blumenfeld, for providing guidance, comments and suggestions at every stage of this thesis. Without him, I could not have completed this.

I'm also grateful to my research participants, who shared their experience and knowledge for this study.

I further wish to thank Dr Kan Wang (CULR) and Prof Zuping Zhao (CULR) for supporting me during my research journey in China. They helped me to get access to my research participants, which is meaningful for this study.

My sincere thanks also go to Pip Desmond for her patient guidance in proofreading this paper.

Last, I am indebted to my family for supporting me finish my study. 


\section{Table of Contents}

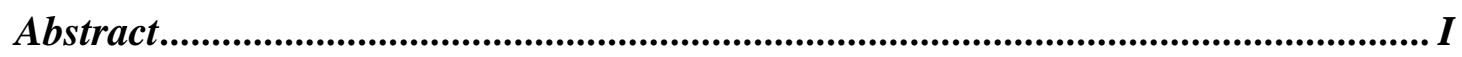

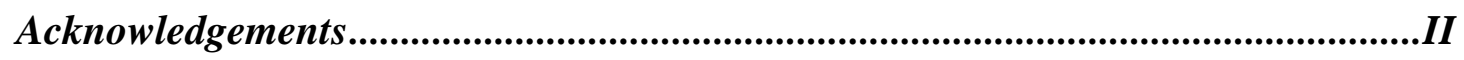

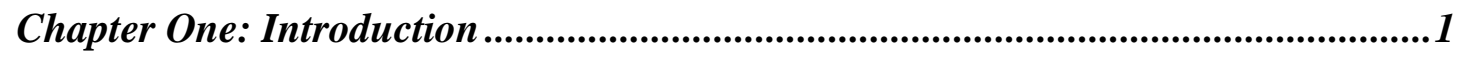

1.1 Background and Research Gaps................................................................... 1

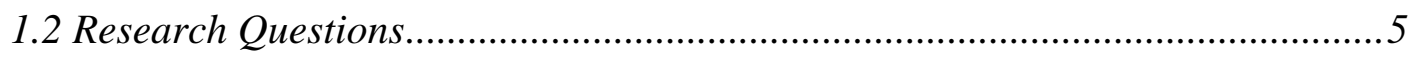

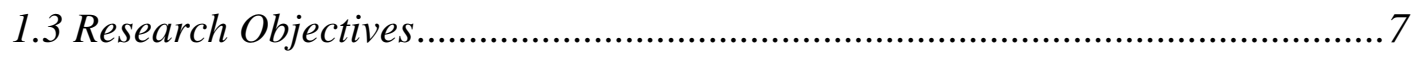

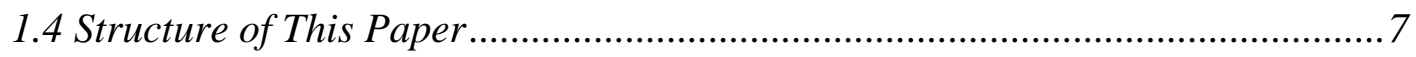

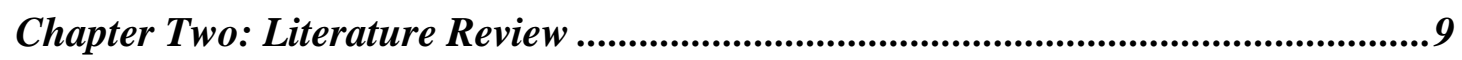

2.1 Social Movement Theories and Grassroots Labour Movements in China ..........9

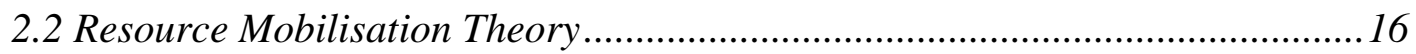

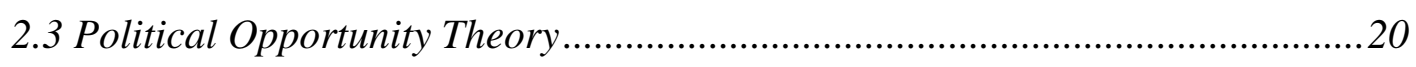

2.4 Transnational Advocacy Network Theory ......................................................24

2.5 Stakeholder Theory in the Social Movement Domain......................................26

Chapter Three: Research Methodology ..........................................................30

3.1 Research Paradigm and Qualitative Approach .................................................30

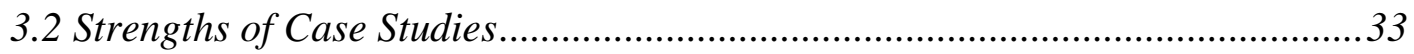

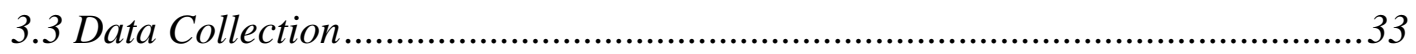

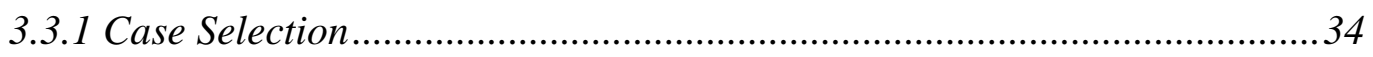

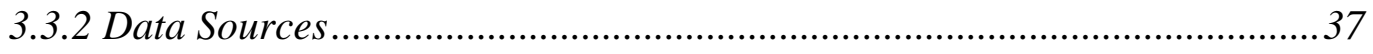

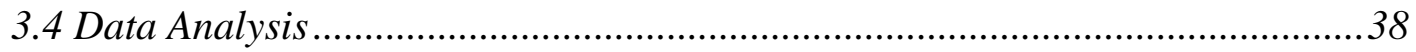

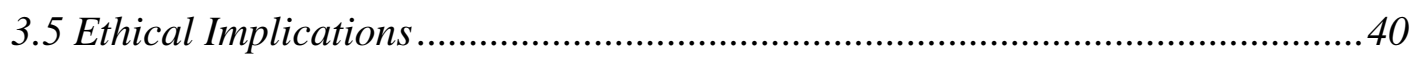

Chapter Four: Research Findings ......................................................................42

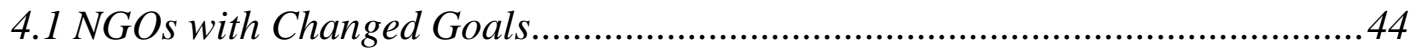

4.2 NGOs with Unchanged Goals but Changed Strategies ....................................46

4.3 NGOs that Maintained Their Goals and Strategies.........................................54 


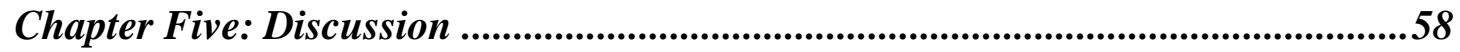

5.1 Targeted Government Tolerance/Repression ...................................................58

5.2 Demographics of Migrant Workers Associated with the NGOs ......................61

5.3 Organisational Size, Structure and Form of Operation ..................................63

5.4 Relationship between NGO Leadership and Government ..............................66

5.5 NGOs' Exposure/Concealment of its Labour Activities ................................... 70

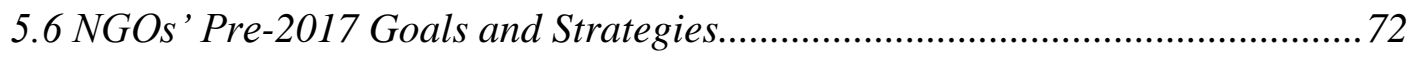

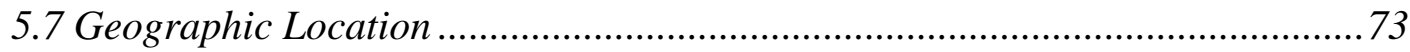

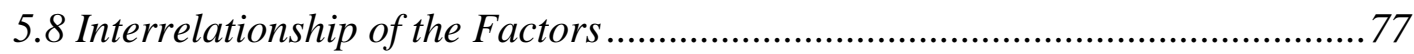

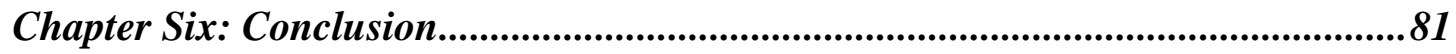

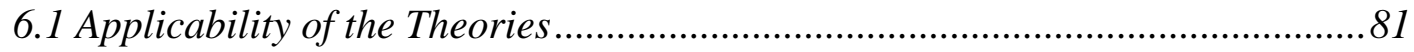

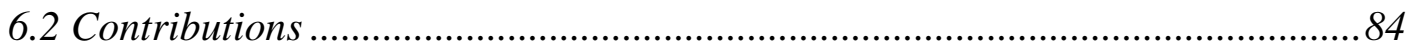

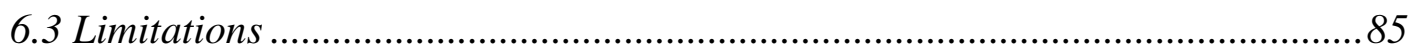

6.4 Suggestions for Future Studies ................................................................... 86

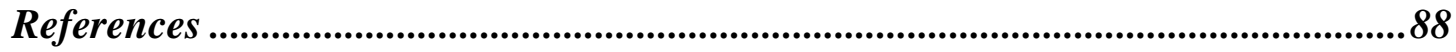

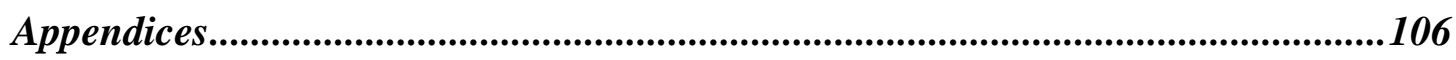

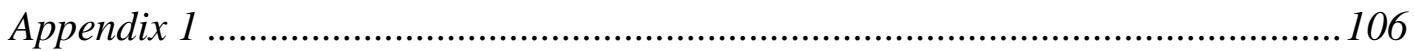

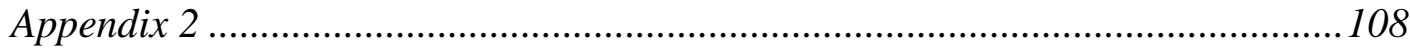

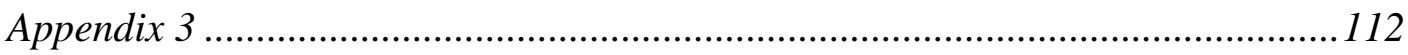




\section{List of Figures}

Figure 2.1: Aberle's Four-Type Social Movements Model...............................12

Figure 3.1: Distribution of NGOs Providing Labour-Related Services in Mainland China (According to Province)

Figure 3.2: Number of NGOs Providing Labour-Related Services in Beijing, Tianjin and Yunnan Province

Figure 3.3: GDP Per Capita of Beijing, Tianjin and Yunnan Province in 2018..36

Figure 3.4: Assumptions about Changes to Labour NGOs' Goals and Strategies

Figure 4.1: Pre-2017 and Post-2017 Goals and/or Strategic Choices of the Labour NGOs Studied.

Figure 5.1: Interaction Between the Causal Factors Affecting the Post-2017

Goals and Strategies of Labour NGOs 
Abbreviations

ACFTU

CNY

CPPCC

GDP

GPS

LGBT

NBSC

NGO

NPC

NSMs

OECD

PO

$\mathrm{RM}$

SCSMs

SMOs

TAN

VBN

UK

US
All-China Federation of Trade Unions

China Yuan

Chinese People's Political Consultative Conference

Gross Domestic Product

Governmental Purchasing of Services

Lesbian, Gay, Bisexual, and Transgender

National Bureau of Statistics of China

Non-Governmental Organisation

National People's Congress

New Social Movements

Organisation for Economic Co-operation and

Development

Political Opportunity

Resource Mobilisation

Social Constructionist Social Movements

Social Movement Organisations

Transnational Advocacy Networks

Value-Belief-Norm

United Kingdom

United States 


\section{Chapter One: Introduction}

\subsection{Background and Research Gaps}

During the last four decades, economic globalisation has been accompanied by the rapid development of China's economy and urbanisation. Two-hundred-and-eighty million Chinese rural-urban migrant workers (migrant workers) have become the main labour force of a large number of emerging factories and urban construction (NBSC, 2020). As per the household registration system ('Hukou') in China, migrant workers are defined as those born in rural regions who move to work in urban areas (Chan \& Selden, 2017). As unskilled recent entrants to the urban labour market, they are frequently exposed to harsh working conditions, such as unpaid wages, excessive working hours, forced overtime, and a variety of occupational health and safety hazards (Fitzgerald et al., 2013; Zhang \& Wu, 2017). In general, they are denied their labour rights, earn 'poverty wages' and work in industries or regions in which the country's labour laws either do not apply or are poorly enforced. A lack of labour representation exacerbates the problems that Chinese migrant workers face.

The All-China Federation of Trade Unions (ACFTU), China's only officially recognised and lawful representative of workers' interests, continues to function as an arm of the state (Taylor \& Li, 2007). Consequently, notwithstanding growing pressures to protect workers' interests and rights in the workplace and recent efforts by the government to promote the practice of collective bargaining, industrial action is seldom sanctioned. For this reason, industrial action in China typically takes the form of ad hoc grassroots, worker-led campaigns (Chan \& Hui, 2014). This has afforded an opportunity for labour non-governmental organisations (NGOs), which operate informally to advise and support workers in labour disputes, to gain a foothold in China.

As the concentrated manifestation of grassroots labour movements, 'labour NGOs' in the previous literature are defined as those NGOs which adhere to their goals focused 
on solving certain labour issues, such as wage arrears, occupational injuries and other labour rights protection (Ford, 2006; Howell, 2015). This definition is employed in this study as well. The size, structure, capacity, goals, functions and financial sources of labour NGOs operating in mainland China are varied. Compared with traditional trade unions in the west, labour NGOs in China are generally smaller, more task-oriented and engage less in developing their membership (Howell, 2015). Since their emergence in mainland China in the mid-1990s, labour NGOs have served as de facto worker representatives.

By conducting grassroots labour movements, labour NGOs are committed to safeguarding the rights of marginalised workers, who are mainly rural migrant workers (Friedman \& Lee, 2010). To distinguish them from official and state-led labour activities conducted by the ACFTU, the term 'grassroots labour movements' in this study refers to those informal and emerging labour movements organised by Chinese labour NGOs.

According to Alinsky (1971) and Ganz (2005), the establishment and implementation of goals and the choice of corresponding strategies play a key role in the development of social movement organisations. The goals and strategies of labour NGOs reflect the development status of the organisation, the needs of the migrant workers and the focus of the labour policies. However, the existing literature rarely considers the development of labour NGOs in terms of their goals and strategies. Thus, this study discusses labour NGOs and their grassroots labour movements on behalf of migrant workers from the perspective of goals and strategic choices. No assessment of the efficacy of any goals or strategies is made. Rather, the focus of this research is on the choice of goals or strategies used by different labour NGOs in Beijing, Tianjin and Yunnan Province, the reasons the NGOs see those goals or strategies as being most viable, and other contingencies and environmental constraints they considered in the selection of those goals or strategies. 
In the two decades after their emergence in mainland China, the development of labour NGOs experienced a dramatic rise and decline. After their tentative infancy, they rose rapidly in the Hu Jintao and Wen Jiabao period from 2002 to 2012. The policies implemented during this period (i.e. the Labor Contract Law and the Labor Dispute Mediation and Arbitration Law in 2008 as well as the Social Insurance Law in 2011) paid great attention to labour issues such as employment, work injury, labour contracts and social insurance. Therefore, the authorities acquiesced in the role played by labour NGOs in supporting grassroots workers. Emerging grassroots labour movements also mushroomed.

During this period, labour NGOs developed several typical strategic activities as follows (Chan, 2013; Xu, 2013; Franceschini \& Lin, 2019):

- $\quad$ building up migrant workers' centres to provide professional training, personal interest classes, entertainment activities and legal aid;

- $\quad$ engaging workers in consciousness-raising outreach programmes on labour rights, which are conducted outside the workers' centres;

- $\quad$ conducting policy advocacy through various social surveys;

- $\quad$ facilitating collective bargaining; and

- $\quad$ mobilising militant collective labour actions.

Although there are few strategic studies of Chinese labour NGOs, the limited number all mention the strategies above. Correspondingly, the four theories - Resource Mobilisation (RM), Political Opportunity (PO), Transnational Advocacy Networks (TAN) and Stakeholder theory - dominate the literature explaining grassroots labour movements and labour NGOs in China during this period. Nevertheless, there is insufficient evidence to say they are still unchanged, especially after the change in the political climate in 2017. 
Specifically, a series of policies that aimed at weakening grassroots social movements was introduced in the period of President Xi Jinping. This particularly affected grassroots labour movements. Since their emergence in mainland China, the funding sources of labour NGOs have mainly relied on overseas donations (including foreign foundations, enterprises, governments, international NGOs and individual sponsors) as well as a small number of domestic donations and governmental funding (Xu, 2013; Spires et al., 2014; Howell, 2015). The Charity Law of the People's Republic of China which came into effect in 2016 regulated that the establishment of all non-profit organisations operating for charitable purposes must be approved by local civil affairs authorities. Moreover, all domestic donations to NGOs operating in mainland China must also be approved by the local civil affairs department. Although this law limited the activities of labour NGOs to some extent, it did not fundamentally threaten their survival because their main sources of funding were overseas donations.

However, in 2017, the Law of the People's Republic of China on Administration of Activities of Overseas Nongovernmental Organizations in the Mainland of China (referred to as the Overseas NGOs Management Law) was introduced. This law puts strict limits on the activities of foreign foundations and other sponsors of NGOs operating in mainland China, as it requires all the activities of overseas NGOs, foundations, and their cooperating partners in China to be approved by the local police department. For labour NGOs in particular, the implementation of the law has excluded almost all their overseas financial sponsors. Since 2017, therefore, it seems that the funding sources of labour NGOs have relied solely on domestic social donations and government funding. Government funding primarily refers to 'Governmental Purchasing of Services (GPS)' from social organisations that initially began experimenting in Guangdong Province in 2008. In a GPS project, the government transfers its public services to social organisations by purchasing their services. However, because of the government's strict requirements for the selection of those 
NGOs, only a few labour NGOs have been able to successfully contract for GPS projects and gain access to financial support from the government (Howell, 2015). Moreover, the GPS restricts the activities of labour NGOs to a 'safe area' permitted by the authorities. Therefore, it is unclear how the Overseas NGOs Management Law has impacted on NGOs' goals and strategic choices since 2017. Also, the applicability of the four main theories might have changed now.

Accordingly, it is reasonable to ask whether, after 2017, labour NGOs operating in mainland China have stuck to their previous goals and strategies. What factors have influenced the goals and strategic choices of these NGOs? And has the applicability of the four theories on grassroots labour movements changed since increasing restrictions on labour NGOs by Chinese authorities reached their peak after the introduction of the Overseas NGOs Management Law in 2017? The topic of labour NGOs has become extremely sensitive as well. It is more difficult for researchers to approach them in China. For that reason, studies on changes in labour NGOs influenced by the policy have not been updated in a timely manner since 2017 .

\subsection{Research Questions}

The goals of labour NGOs generally remained unchanged during their first two decades of existence in mainland China, and these are clearly elaborated in the existing literature. Nonetheless, recent experience suggests that those goals, and the strategies used to achieve them, may be changing as China and its government confront distinctive economic and political challenges. So it makes sense to ask: What are the goals of NGOs providing different services? Are these goals all the same? Have these goals changed since 2017 ? If so, what are the causes of these changes?

Scholars studying these organisations have also all but ignored the crucial element of strategy, focusing instead on the context and the opportunities and challenges 
environmental factors pose for the successful achievement of those goals. That is, research on Chinese labour NGOs attributes the formulation of their strategies to the political climate, rather than to the formulation of goals (Gleiss, 2014; Hsu \& Jiang, 2016). Howell and Pringle (2019), for instance, point to the authoritarianism of the Chinese government as the main factor restricting the development of informal labour organisations in China. By the same token, Franceschini (2014) suggests the success of Chinese labour NGOs is determined by the relationships they forge with external stakeholders, including the government and their sponsors. Therefore, the second research question is: What are the strategies of labour NGOs to achieve their set goals? Have these strategies changed? Why were they changed? What are the difficulties encountered in implementing the strategies?

Accordingly, the present research will be conducted around the research question: 'What factors influence the current goals and strategic choices of labour NGOs operating in Beijing, Tianjin and Yunnan Province in representing rural migrant workers?' Specifically, the research question can be classified as the following four sub-questions:

1. What are the current goals of the target labour NGOs in representing rural migrant workers? Have these goals changed, especially after the 2017 Overseas NGOs Management Law? If so, how and why?

2. What strategies are the target labour NGOs currently applying to accomplish those goals? Have those strategies changed since 2017 ? If so, how and why?

3. What factors influence the goals and strategic choices of the target labour NGOs? And how do these factors affect NGOs' goals and strategic choices?

4. Most importantly, has the applicability of the four main social movement theories to explain the target grassroots labour NGOs changed? If so, what changes have occurred? And why have they changed? 


\subsection{Research Objectives}

A qualitative research approach drawing on 15 semi-structured interviews conducted with the founders, managers and staff in 10 labour NGOs operating in Beijing, Tianjin and Yunnan Province has been applied in this study. To accurately answer the research questions above, the objectives of this research are presented as follows:

1. to discover the current goals and strategies of labour NGOs;

2. to compare changes in the goals and strategies of labour NGOs before and after 2017

3. to identify the underlying factors and their impacts in affecting the goals and strategic choices of labour NGOs;

4. to clarify the current applicability of the four main social movement theories when explaining grassroots labour NGOs.

\subsection{Structure of This Paper}

This research aims to identify the factors influencing the goals and strategic choices of labour NGOs in Beijing, Tianjin and Yunnan Province. It has six chapters including the introductory chapter.

Chapter Two reviews the history and kinds of contemporary social movements, and the development of corresponding theories of these social movements. The focus of this chapter is on the discussion of the four main social movement theories which dominate the studies of grassroots labour movements of Chinese labour NGOs, including the advantages and disadvantages of these theories, followed by assumptions about their current applicability.

Chapter Three discusses the methodologic choice of this study. It explains the philosophical foundation and the selection of the qualitative research approach and case 
study methods in this research. The process of data collection and data analysis, and the consideration of potential ethical issues are also included.

Chapter Four presents the research findings specific to the comparisons of the pre2017 and post-2017 goals and strategies adopted by each labour NGO studied.

Chapter Five identifies the factors affecting the post-2017 goals and strategic choices of labour NGOs. It analyses the interactions of these factors and evaluates the influence of each factor. It also tests the applicability of the four main theories reviewed in Chapter Two.

Chapter Six concludes the research and provides answers to the research questions. It clearly indicates the applicability of the four theories to the goals and strategies of labour NGOs in the context of China. Finally, it proposes possible research directions for future studies. 


\section{Chapter Two: Literature Review}

\subsection{Social Movement Theories and Grassroots Labour Movements in China}

Initially introduced by von Stein (1848), the term 'social movement' has been widely used by sociologists and political scientists to refer to a variety of collective movements and campaigns which have arisen since the early 1960s in western countries. In the 1970s, American community activist and political theorist Saul Alinsky (1971) systematically theorised and integrated a more complete theory of social movements which he used to explain the early American human rights campaigns and ethnic movements of a decade earlier. Since then, social movement theory has been developed and applied to purposeful, structured strategies and collective action aimed at empowering oppressed groups all over the world. Correspondingly, social movement organisations (SMOs) are an important component and manifestation of a social movement, as their role is organising and coordinating social movements. An SMO normally serves only one social movement while a social movement may contain large number of SMOs (Zald \& McCarthy, 1987).

When it first entered the lexicon of modern social sciences, the term 'social movement' was narrowly defined as a series of radical, single and ongoing acts of collective struggle inspired by anomie, the absence or loss of social norms or values in society (Durkheim \& Karady, 1975). Early sociologists and political scientists generally attributed the emergence of a social movement to the participants' grievances at being deprived, which was later regarded as the classical Relative Deprivation theory of social movements (Blumer, 1946; Kornhauser, 1959; McAdam, 2010). Nevertheless, between the mid-1970s and early 1990s, two dominant paradigms of contemporary social movements emerged in the US and challenged traditional thinking. Resource Mobilisation (RM) theory, on the one hand, argues that the success of social movements depends on the availability of resources - time, money, skills, etc. - and the ability to use them. It assumes that all participants can rationally evaluate the costs and rewards 
in a social movement (McCarthy \& Zald, 1977). On the other hand, political opportunity (PO) theory - also referred to as political process theory - posits that the success or failure of social movements rests on the existence of political opportunities. It describes a social movement as a game between the power challengers and the main regime, and as having a strong political purpose (McAdam, 2010).

Manifestations of student and labour unrest in Europe during the 1980s and first half of the 1990s gave rise to the third category of social movement theory. Known as New Social Movements (NSMs), this theory attempts to explain the growing prevalence of wider civil and cultural unrest around the world. NSMs theory departs significantly from conventional social movement paradigms which mainly focus on political and economic issues but it also aims to effect change (Buechler, 1995). Typical activities emphasised by NSMs theory include sit-ins, demonstrations and other forms of civil disobedience and modest collective action. Rather than expanding participants' influence to gain power, NSMs theory tends to highlight the significance of promoting the self-consciousness and ability of participants in a social movement (Rucht, 1988).

After decades of vigorous development, theories about social movements are numerous. It is possible, however, to distinguish between two broad archetypes within social movement theory: the European and the American paradigms. Regardless, from the 1990s onward, these two different theoretical systems combined to produce various other theories of social movements. For example, first proposed by Morris and Mueller (1992), Social Constructionist Social Movements (SCSMs) theory regards social movements as a process that allows members to build new social consensus and even beliefs through a series of intimate connections and the use of political and cultural symbols. As well as, realising the drawbacks of PO theory and RM theory, Morris (2000) introduced another new theory called Cultural theory, which recognises that emotional and psychological factors affecting individuals also play a significant role in social movements. These various theories enrich understanding of contemporary social 
movements. Accordingly, the definition of social movement has been gradually reshaped as a kind of collective action that occurs when the original economic, social or cultural structure breaks down and new alternative structures are built (Morris, 1999; 2000).

Over time, social movements have increasingly become more complex and diverse. The types of social movements discussed in the literature have also grown since the 1950s in addition to examples which existed before World War II, such as suffrage movements or labour movements. Other emerging social movements like civil rights, environmental, feminist, LGBT, peace and anti-nuclear movements have been added to the mix and have broadened the range of examples used to illustrate what is meant by a social movement (Lin, 2020). The theories related to these specific social movements have also developed correspondingly. In terms of environmental movements, for example, Stern et al. (1999) propose VBN (value-belief-norm) theory based on the resource mobilisation paradigm to demonstrate the facilitating factors of environmental movements. While combining the basic theories of social movements and the gender process and gender frame theory, feminist scholars have also formulated a series of new theories for the development of women's movements (Taylor, 1999; Ferree \& Merrill, 2000). In the labour movement domain, after 2000, Transnational Advocacy Network (TAN) theory became a crucial theory to explain rising international labour movements (Sage, 1999) and the transnational strategies of many trade unions in the west (Fonow \& Franzway, 2007). Stakeholder theory has also been introduced to analyse the development of SMOs such as trade unions and labour NGOs (Ackers \& Payne, 1998; Rawling, 2006). Thus, the applicability of any theory to contemporary social movements depends, in large measure, on the type of social movement being described.

This study explores the grassroots labour movements of labour NGOs in the context of China. A grassroots labour movement is different from traditional labour movements 
and other kinds of social movements above. For the purpose of clearly distinguishing a grassroots labour movement from other social movements, this study classifies it as an alternative social movement based on the four-type social movements model proposed by Aberle (1966).

Figure 2.1: Aberle's Four-Type Social Movements Model

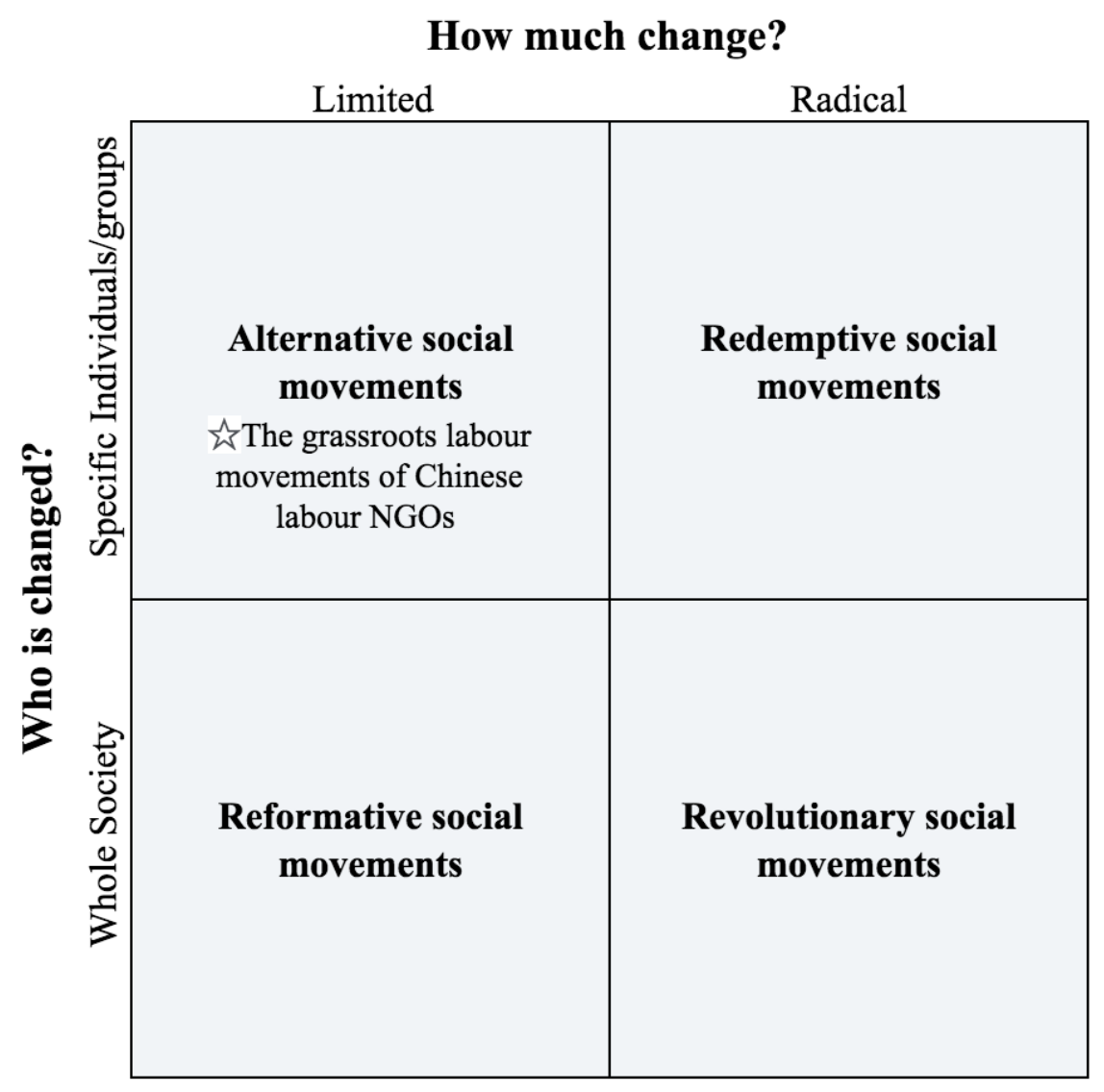

Source: The Peyote Religion among the Navaho, Aberle (1966)

The model (see Figure 2.1) places social movements into one of four categories, according to whom a movement aims to change and how much change is sought. Alternative social movements arise in minority groups in society and seek limited change. Typical examples are unions that advocate for workers' rights. Chinese grassroots labour movements also belong to this category because labour NGOs operating in China are said to have chosen to work within the legal structures of the state to effect limited change and improvements for their members (Domingo and 
O’Neil, 2014). Many scholars often apply RM theory, PO theory, TAN theory and Stakeholder theory to explain social movements in this category. Redemptive social movements normally involve only one marginalised group and attempt to fundamentally change social consensus about them. Successful redemptive movements (e.g. the early women's suffrage movement all over the world, the African-American civil rights movement and the LGBT movement for same-sex marriage) often promote legislation in a country to achieve results through a series of radical activities. RM theory and PO theory are the most common theories that analyse the emergence and development of redemptive social movements in the previous literature. Reformative social movement activists only aim to change a social phenomenon to the limited extent to which they are unsatisfied, but their activities generally affect the whole society, as in the case of environmental, anti-nuclear and peace movements. NSMs theory, SCSMs theory, Cultural theory and VBN theory have all developed from this type of social movement. Revolutionary social movements such as the American Revolution in 1776, the French Revolution in 1789 and the October Revolution in Russia in 1917 often attempt to change political institutions or regimes. During revolutionary movements, the classical Relative Deprivation theory is the dominant theory in the field.

As grassroots labour movements in China are alternative social movements, many studies of them mainly adopted RM, PO, TAN and Stakeholder theories that developed in western social movements. However, even theories about the same type of social movement may not be applicable to similar movements in other political, social and economic contexts. Escobar (2005) demonstrates that these theories in the social movement domain learnt from developed countries cannot be accurately applied to less developed economies. Also, social movements may differ, even within a given country, across cultures, in who they target and the changes they advocate.

The same can be said of theories of social movements, which can be applied in different ways, and are context-specific. Bevington and Dixon (2005) argue that 
because each theory may not be fully applicable to contemporary circumstances and contexts, established theories of social movements frequently need to be integrated and modified to remain relevant. This applies especially to countries that are undergoing rapid economic and social transformation, as China has over the past two decades.

The focus of this study, therefore, is on the applicability of the four common theories of alternative social movements to grassroots labour movements in different regions of China. The principal research question to which an answer is sought is: What do social movement theories contribute to the understanding of contemporary Chinese labour NGOs in representing the interests of rural migrant workers in China, especially in the context of policies weakening labour NGOs since 2017 ?

To understand this question better, it is necessary to briefly draw on the relationship between the development of labour movements worldwide and grassroots labour movements in China. From the perspective of historical materialism, the rise and decline of western collective labour action and labour movements have followed the progression of social and economic development (Nilsen \& Cox, 2013). During periods of major economic restructure and political turbulence, collectivism has been shown to be an effective and situationally specific response to employer-generated injustice (Kelly, 2012). For instance, the earliest labour movements emerged in the initial industrialised democracies. This was soon followed by the formation and establishment of trade unions (Ebbinghaus \& Visser, 2000). Those original labour movements experienced their greatest period of expansion in the aftermath of the Great Depression of 1873-96, typically reaching their peak during the economic boom of the post-war era, which effectively ended during the oil crunch of the 1970s. Those movements characteristically involved workers joining together in a fight against capital and state political control in favour of better pay, hours of work, working conditions and basic rights at work (Hancké, 1993; Lichtenstein, 2013). 
By contrast, the last four decades have witnessed the global integration of capital markets, a principal driver of globalisation and a hallmark of the increasingly globalised economy, and the rise of neoliberalism. These changes precipitated a lasting decline in labour movements in most western countries. In cultures and societies where individualist social and political norms and mores have held sway over collectivist values and ideals, as exemplified by the US, no labour movement has ever managed to amass a sizable share of the total labour force. Yet, even in countries where trade unionism experienced a more advantageous trajectory and occupied considerable space in the social, economic and political arenas during the first three-quarters of the twentieth century, trade unions have experienced a marked decline in their power and influence (Bryson et al., 2011; OECD, 2018).

Contemporary industrial relations scholars tend to view all labour movements through a western lens and apply social movements theories developed to explain the emergence of labour movements in western countries, most of them well over a century ago. However, this study argues that popular social movement theories offer only a partial explanation for the development of grassroots labour movements in China and, in particular, the strategic role of labour NGOs in that process. This is especially true of specific aspects of these theories with regard to the current status (since 2017) of labour NGOs in China vis-à-vis the ACFTU, the country's 'official' labour movement. Grassroots labour movements in China emerged much later than traditional social movements in the west. Nor has the ACFTU played a significant role in encouraging workers to conduct grassroots labour movements in a de facto sense. Instead, as the real voluntary SMOs of workers that organise collective labour action, Chinese labour NGOs only emerged around 20 years ago. Nevertheless, as the main grassroots labour movement organisations, they have benefited greatly from the existing theories and experience of the west. In fact, almost all the current mainstream theories used to explain labour NGOs in China have been learnt from western theories discussed above. 
Among these theories, RM theory advocates that the structural conditions formed by the new labour movements should be discussed from the perspective of the SMOs. It also indicates that the roles and conditions of the formation of Chinese labour NGOs are a process of rational choice. PO theory is also widely used because almost all scholars who study Chinese labour issues insist that political factors have the most crucial effect on the labour movements. In addition, TAN theory and Stakeholder theory, which have become the new focuses in the study of labour NGOs in recent years, explain to a greater or lesser degree the specific strategies of labour NGOs in China.

Based on the relevance of western social movement theories, this chapter reviews the main theories which are most widely used by theoretical and empirical researchers to discuss grassroots labour movements and labour NGOs in China. These are RM theory, PO theory, TAN theory and Stakeholder theory. It also analyses the strengths and weaknesses of each theory and then makes assumptions about which theories, or aspects of them, are still applicable to grassroots labour movements in China and which theories or aspects of them are not applicable.

\subsection{Resource Mobilisation Theory}

In recent decades, many scholars in China have widely used RM theory to explain grassroots labour movements. However, the present study challenges RM's ability to fully explain the current goals and strategic choices of labour NGOs in China. As an essential theory of social movement studies, RM theory was developed in the 1970s in the US and gradually became a dominant research paradigm of social movement theories. As distinct from the classical Relative Deprivation theory which highlights collective grievances are the main trigger of social conflicts, RM theory interprets social movements or collective action as the consequences of rational choices and resource manipulation by people (McCarthy \& Zald, 1977; Mancur Jr, 1968). 
To be more specific, applying basic economic principles, RM theorists assume social movement participants are always rational. The emergence and development of a social movement are thus the result of people rationally weighing up the investment and rewards of the participation in movement when institutional changes occur. Theorists also highlight that differences in available resources, organisational strategies, and the opportunities for movements are the main factors that influence the success of a social movement. Another significant characteristic of RM theory is that the main conflicts of interest between the dominant power and the power challenger determine the main objectives of a social movement (Jenkins, 1983). In fact, RM theory implies three preconditions for the emergence of a social movement: a) the leadership of the movement are elites, b) they have enough available resources to mobilise and c) all decisions made by movement participants are rational.

In the decades since its emergence, debates over RM theory have never stopped. Although this theory provides a relatively comprehensive explanation for a series of social movements in the US from the 1960s to the mid-1980s, scholars widely critique RM theory as it has obvious defects (Bevington \& Dixon, 2005). This is even recognised by McCarthy and Zald (2001), the originators of the theory in the previous literature.

There are many branches of RM theory, but it can be generally divided into two main research focuses: social movement organisations (SMOs) and the political context of movements. Some concepts from both focuses still play a key role in contemporary social movements. From SMOs' perspective, one of the greatest advantages of RM theory is that, besides substantive resources such as money, supplies and equipment, the role of organisational strategies and leadership is highly valued, which is still very important in modern social movements (Oberschall, 1973; McCarthy \& Zald, 1973; 1977; Tilly, 1977). Another advantage is that it takes the lead in affirming the important role of the political environment in historical social movements. This is a key factor 
that made the theory dominant in this field in the 1970s and 1980s. Until then, social movements had paid little attention to structural factors other than those related to the groups within the movement (Oberschall, 1973).

However, scholars constantly critique or partially critique the applicability of RM theory to the interpretation of contemporary social movements. As Buechler (1993) shows, RM theory's superiority in the field of social movements has only been demonstrated for a specific historical period. With the continuous development of social movements, the weaknesses of its core hypothesis make it ineffective or less effective in explaining and analysing current social movements. Although there are different critiques of RM theory in different social movements, this research identifies two major weaknesses in explaining grassroots social movements.

The foremost weakness of RM theory is that it cannot explain how groups with fewer resources conduct social movements. In fact, grassroots social movements continuously arise all over the world, even with very limited resources. The leadership of these movements are normally non-elites who have fewer resources to mobilise. Missingham's study (2003) is an example of how poor people in Thailand launched a successful national environmental campaign. Thousands of social movements led by poor people in South Africa since the beginning of this century also confirm that resource-limited groups can conduct influential social movements (Alexander \& Pfaffe, 2014). The grassroots labour movements discussed in the present research are also a social movement conducted by Chinese workers with few resources. Therefore, it is reasonable to challenge whether RM theory is fully able to explain grassroots labour movements in China.

Another notable weakness of RM theory is its basic assumption that participants are rational. RM theorists believe the emergence of social movements depends on completely rational choices about existing resources but ignore the effects of emotional factors on collective movements. During the past two decades, more and more social 
movement researchers and activists have realised that it is impossible to remove collective grievances from the causes of collective behaviours (Goodwin et al., 2000; Gould, 2004; Jasper, 2008; Ruiz-Junco, 2013). The re-emphasis on the effect of emotional factors on social movements was initially strengthened by the early modern women's movements and other cultural movements and has since been generalised to include almost all kinds of social movements (Goodwin et al., 2009). For instance, Goodwin and Pfaff (2001) revealed the importance of emotional management in deciding the successful achievement of civil movements by analysing numerous American and German cases. Ahmed et al. (2017) have also confirmed that emotional factors play a significant role in the newest online movement in India.

The strengths and weaknesses of RM theory are also obvious in the studies of grassroots labour movements and labour NGOs in China which apply this theory. Regarding its strengths, the emphasis on the effect of resource mobilisation on resources, organisational strategies, leadership and the political environment has long been the focus of labour NGOs in China. Chen and Yang (2017) illustrated the significant influence of leadership on their radical movement strategies based on their study of labour NGOs in the Pearl River Delta region. Scholars are also interested in how Chinese labour NGOs legitimise their identity and continue to represent workers under the current legal system (Gleiss, 2014; He \& Huang, 2015). Moreover, there is no doubt that all the research on Chinese labour NGOs points to the impact of the political environment on grassroots labour movements especially after the introduction of the Overseas NGOs Management Law in 2017. Since then restrictions and supervision of these labour NGOs have reached a peak (Franceschini \& Nesossi, 2018), and the influence of the factors above on labour NGOs is bound to increase. Therefore, the study assumes that the perspectives of RM theory above are still significant in the current context but their impact may vary from region to region. 
Nevertheless, the weaknesses of RM theory are also shown in the literature about Chinese labour NGOs. Previous studies attribute the emergence of labour NGOs in China to the lack of representation for grassroots workers (Chan, 2013) and the urgent demand for collective action due to growing employment conflicts (Friedman \& Lee, 2010; Franceschini \& Lin, 2019). Few scholars attempt to explore the collective grievances of workers caused by various structural contradictions, and how emotional responses shape labour NGOs and grassroots labour movements. Most importantly, previous scholars who applied RM theory do not explain why grassroots NGOs with very limited resources can still develop labour movements in China.

Accordingly, this thesis assumes that RM theory cannot fully explain the goals and strategic choices of labour NGOs in China, especially after 2017. The theory is still of great significance to the current grassroots labour movements in China because of its emphasis on organisational strategies, leadership and the political environment. However, it may not explain the development of Chinese labour NGOs as most of them have fewer resources. Scholars may also ignore emotional factors if they utilise RM theory to explain grassroots labour movements.

\subsection{Political Opportunity Theory}

As others studying social movements have observed, in the context of an authoritarian political state in which there is minimal political mobilisation and suppression of antigovernment activities, the dominant factor determining the strategic direction of independent organisations is the legal framework, which is characteristically designed to maintain the authoritarian equilibrium (Xie \& Van Der Heijden, 2010; Howell, 2015; Lin, 2020). The central paradigm put forth to explain the emergence and sustainability of social movements under authoritarian rule is PO theory. Also known as Political Process theory, its proponents posit that political opportunities are the principal driver 
of social movements and determinant of their sustainability (Morris, 1986; Morris \& Mueller, 1992; McAdam, 2010). By creating new paths or opening existing avenues for public discourse, mutable political opportunities enhance the ability of citizens' groups to mobilise a constituency around an issue or cause and influence change.

This section reviews the literature on PO theory, with an eye towards gaining insight into its applicability to the study of grassroots labour movements in China. Since the emergence of PO theory in the US in the mid-1990s, it has dominated the research domain of social movement theory. Despite this ascendency, in recent years many western scholars have begun to challenge and criticise its purported merits as a comprehensive theory of social movements (Gamson \& Meyer, 1996; Goodwin \& Jasper, 1999; Goodwin \& Jasper, 2004; Gould, 2004; Goodwin et al., 2009; Giugni, 2011). Nevertheless, given the relative dearth of scholars who have critically evaluated its applicability to social movements in the milieu of authoritarian state control, few have challenged the orthodoxy of PO theory in the context of the People's Republic of China.

Developed from the political environment aspect of RM theory, PO theory is a variant of RM theory. Both the two theories emphasis that the political environment from which a social movement is generated decides the emergence, development and achievement of the movement (Meyer, 2004). However, there is a significant difference between them. The basic assumption of RM theory implies a social movement only occurs when the core participants of the movement are social elites with enough resources (McCarthy \& Zald, 1977). PO theory overcomes this weakness since it assumes that even groups with few resources can successfully conduct movements once they grasp appropriate political opportunities (Morris, 1986; McAdam, 2010). Therefore, since it began to dominate the study of social movements, PO theory has provided a novel and powerful insight for analysing social movements. This has promoted extensive related research on social movements in the decades following its 
development. The definition of political opportunity employed in this study is proposed by Giugni (2011). It sums up his predecessors' cognitions about 'political opportunity' (Eisinger, 1973; Tilly, 1977; Meyer \& Minkoff, 2004; Giugni, 2011) and conceptualises the term as the external dimension(s) that could influence the ability of the movement to mobilise in a complicated and wide political context. PO theory is particularly relevant to explain how a certain public policy can strengthen or weaken social movements and how political opportunities can shape the structure and features of a social movement and its SMOs (Gamson \& Meyer, 1996; Tarrow, 1996; Giugni, 2011).

Although it has dominated the social movement domain over the past two decades, PO theory has two weaknesses that cannot be ignored. Foremost of these is that scholars of PO theory are prone to exaggerate the effect of political opportunity on social movements, stubbornly holding to the view that political opportunity is the only decisive factor in the success or failure of a social movement. As Goodwin and Jasper (1999) contend, the political process model is 'invariant' (p. 30). That is, advocates of PO theory frequently attribute the rise and fall of social movements to whether the political system provides the right opportunities for them to flourish. As with RM theory, this directly excludes emotion, culture and ideology as possible causes of social movements, which is one of the significant critiques of PO theory as well (Goodwin \& Jasper, 2004; Gould, 2004; Goodwin et al., 2009). Yet, while a relaxed political environment is critical to the launch and development of a social movement, there is ample evidence to suggest that social movements do not necessarily disappear when faced with few, if any, political opportunities. Even in the most restrictive political climates, when faced with irreconcilable conflicting interests between the challenger and those in power, SMOs established as part of a social movement will alter their strategies in order to survive. This is evident in large number of social movements in recent history, from the Emmeline Pankhurst era of the British suffragette movement 
to the civil rights movement in the US (Alinsky, 1971) and modern labour movements across the world (Baccaro et al., 2003; Lin, 2020). These movements do not always have favourable political opportunities during their emergence and development, and may even have been suppressed by the regime in that period. Nonetheless, because of the conflicting interests do not weaken because of the adverse political environment, sponsors, activists or organisations of those social movements adopt all kinds of strategies to promote the movements.

Another notable weakness of PO theory is that it tends to extend indefinitely and attempt to include all aspects of social movements. As Gamson and Meyer (1996) state in their article, 'Framing Political Opportunity', the term 'political opportunity' has become a 'sponge' (p. 275) to absorb all external factors associated with social movements. Goodwin and Jasper (1999) also challenge this inappropriate expansion of the concept because of its ambiguous identification with structural factors to create a social movement. It is possible for theorists of social movements and those who use the theory to explain a particular social movement by simply attributing complex circumstances to political opportunity and ignoring other potential factors.

In the context of China, PO theory has occupied an important position in explaining various social movements (Xie \& Van Der Heijden, 2010; Chan \& Zhou, 2014; Lin, 2020). Notably, the previous literature has confirmed that political opportunity poses a greater impact on social movements there than in the west because of the different institutional and legal systems (Corduneanu-Huci \& Osa, 2003). This is particularly evident in grassroots labour movements and labour NGOs (Howell, 2015; Lin, 2020). Therefore, this thesis assumes that political opportunity is a factor that must be considered when discussing the goals and strategies of labour NGOs in the three target regions of China, particularly after 2017. However, due to the potential weaknesses of PO theory, it is also reasonable to assume that lack of political opportunities has not caused grassroots labour movements to perish in China even after a series of policies 
weakening NGOs was introduced in 2017. Labour NGOs operating in mainland China may apply alternative goals and strategies to survive. Besides, it is inappropriate to simply attribute all the factors that affect the goals and strategic choices of Chinese labour NGOs to political opportunities. Instead, it is necessary to recognise and distinguish other structural or non-structural causes when explaining their strategies and goals.

\subsection{Transnational Advocacy Network Theory}

In the late 1990s, with the continuous expansion of economic and political globalisation, a rising theory based on constructivism was widely recognised by sociologists and international relations scientists. Known as Transnational Advocacy Network (TAN) theory, it was also widely applied to the research and practice of trade unions and international NGOs around the world in the following decades (Keck \& Sikkink, 1998; 1999). As distinct from the basic assumption of the 'rational person' in RM theory, TAN theory hypothesises that actors in networks are 'homo sociologicus' (p.506) whose activities are follow on from their self-identity, social norms and limited rationality (March \& Olsen, 1989; Schroeder, 2008). Although various kinds of international cooperation existed for a long while, the term 'transnational advocacy networks' was first defined by Keck and Sikkink in 1998. It refers to the networks established by actors besides states (e.g. trade unions, NGOs, enterprises, scholars and other international organisations) in global politics for the purpose of achieving certain political goals or expanding the international influence of a certain policy. Such networks may connect actors who adhere to the same goals and principles (Keck \& Sikkink, 1999). NGOs, as an important actor in transnational advocacy networks, have been actively involved in networks since the early 1990s (Bryer \& Magrath, 1999). The objects of NGOs' transnational advocacy include various international organisations, 
foreign governments, entrepreneurs, trade unions and other overseas NGOs (Hudson, 2001).

As illustrated in the existing literature, two main advocacy strategies follow from TAN theory: the outside-in approach and the inside-out approach (Santa Cruz, 2004). The outside-in approach mainly refers to the 'spiral model' proposed by Risse et al. in 1999. The spiral model explains the way existing international norms enter a specific country and influence local policy. In the social movement domain, it has been widely used in research about international NGOs and transnational human right movements around the world (Risse-Kappen et al.,1999; Risse, 1999; Fleay, 2006; Alhargan, 2012). However, a human rights study by Shor (2008) in Israel demonstrates some weaknesses of the spiral model. Most importantly, the spiral model underestimates a regime's concerns about security and stability, which can easily lead it to view transnational advocacy by NGOs as threats. The model also presumes advocacy at the national level while ignoring regional differences.

Fewer scholars advocate the 'inside-out' approach (Finnemore \& Sikkink, 1998; Santa Cruz, 2004) to explain how a certain norm developed in a specific country or region is dispersed to other countries. The approach also provides a strategic method for those NGOs seeking to increase power in domestic campaigns by establishing international alliances and expanding international influence. The 'life cycle' model of Finnemore and Sikkink (1998) is typical of the 'inside-out' approach. It proposes a three-phase method: a) how an international norm emerges in a specific country (emergence); b) how international organisations select potential organisations which may accept the norm in other countries to conduct advocacy (norm cascades); and c) how transnational diffusion of the norm (internalisation) is finally achieved.

Since most NGOs operating in mainland China have been more or less supported or influenced by foreign organisations, scholars have recognised the applicability of TAN theory in China (Jie, 2006). However, nearly all research about international NGOs in 
China has adopted the 'outside-in' approach. A typical example is the environmental movement field (Wu, 2005; Yang, 2005; Schroeder, 2008). Scholars argue that the rise of environmental NGOs in China has benefitted from the expansion of international environmental advocacy networks (Schroeder, 2008). Fleay (2006) utilises the spiral model to explain NGOs' advocacy strategies in the human rights movement domain. Other scholars also hold that the emergence of NGOs in China mainly relies on support from overseas (Jie, 2006; Wu, 2005; Yang, 2005; Friedman, 2009).

Most studies on transnational activities of labour NGOs in China applied the 'outside-in' approach more frequently before 2017 because financial support from transnational labour organisations, foundations, foreign-funded enterprises and some foreign embassies played an important role in the emergence and development of grassroots labour NGOs operating in mainland China (Friedman, 2009; Cheng et al., 2012; Xu, 2013; Pringle, 2018). Labour NGOs thus learnt many strategies from those foreign organisations on how to conduct labour movements. Since 2017, however, the Overseas NGOs Management Law has greatly restricted NGOs' overseas financial sources (Franceschini \& Nesossi, 2018). This brings into question the previous application of TAN theory to Chinese labour NGOs which highlighted overseas funding. Therefore, it is reasonable to ask whether TAN theory is still appropriate to discuss the labour NGOs in this study after 2017.

\subsection{Stakeholder Theory in the Social Movement Domain}

Stakeholder theory originally developed from the field of organisational management but a new trend in recent years has seen it used by some scholars to analyse the development of SMOs. Most early theorists of Stakeholder theory focused on the perspective of managers. They emphasised managers' awareness of the interests of their stakeholders, proper management of the relationship with stakeholders and appropriate decision-making as the premises to improve organisational interests at the same time 
as taking corporate social responsibility (Freeman \& Gilbert, 1987; Clarkson, 1995; Harrison \& Freeman, 1999). On this basis, identifying and determining the stakeholders of an organisation and the importance of stakeholders has become a focus (Friedman \& Miles, 2002). Mitchell et al. (1997) contribute to this by proposing a famous threeclass standard to identify the importance of stakeholders: a) the 'power' of a certain stakeholder to affect the organisation; b) the 'legitimacy' of the relationship between the stakeholder and the organisation; and c) the 'urgency' of the problem caused by the stakeholder to the organisation. It assumes that if a stakeholder related to an organisation meets one or more of the standard(s) above, they can be regarded as an influential stakeholder in the development of the organisation.

At present, the research which attempts to apply Stakeholder theory to the study of social movements does so from one of two focuses. The first focus is to determine the stakeholders of SMOs and the management of the relationships with them. In regard to this, although some scholars have attempted to develop new techniques to identify stakeholders of SMOs (Bryson, 2004), the 'power, legitimacy and urgency' standard proposed by Mitchell et al. (1997) is still applied in most related studies. More studies are now concerned with the second focus of taking SMOs as stakeholders of enterprises, governments or other objects. This was developed from the understanding of corporate stakeholder theorists about collective action within the organisation. They regard collective action as a process for secondary stakeholders who are less influential to align with each other and gain a greater voice in the conflicts between their interests (Rowley \& Moldoveanu, 2003; Eesley \& Lenox, 2006; King, 2008). This provides a new explanation for the emergence and development of SMOs. Scholars also emphasise that NGOs, as SMOs in many areas, should rationally evaluate their role as a stakeholder and enhance their voice through increasing power, legitimacy and urgency (Doh \& Guay, 2006). There are numerous examples in the environmental movement field about how environmental NGOs as stakeholders enhance corporate social 
responsibility and promote sustainable development (Murphy \& Bendell, 1999; Arenas et al., 2009; Harangozó \& Zilahy, 2015; Bendell, 2017).

The existing literature from the perspective of SMOs could benefit from a consideration of the combined merits of the two focuses. Specifically, when significant changes occur in the environment in which a social movement is embedded, reidentification of stakeholders of SMOs and their importance needs further development. At the same time, the second focus contributes to explaining the emergence of SMOs, and provides strategies for SMOs to maintain and enhance their role in the movement on the basis of the first focus.

For labour NGOs operating in mainland China, previous scholars have, for the most part, focused their attention on the second research focus of Stakeholder theory. Seeing labour NGOs as the stakeholders of workers, government and international civil society, early scholars have explained the emergence of these NGOs in China accordingly (Morton, 2005; Friedman \& Lee, 2010; Chan, 2013). Most subsequent mainstream studies have taken labour NGOs as stakeholders of the government and their foreign sponsors (Wang, 2008; Chan, 2013; Gleiss, 2014; Howell, 2015; Howell \& Pringle, 2019). However, due to the introduction of policies weakening Chinese labour NGOs, the environment they face has changed dramatically. The current significance of the authorities as a stakeholder of labour NGOs is unclear. Foreign sponsors may not play the same role for those NGOs as they used to. Also, other stakeholders could emerge in the new context. Therefore, this research advocates that it is meaningful to re-identify and re-evaluate the stakeholders affecting those labour NGOs in China as suggested in the first research focus.

Accordingly, it is important to update and clarify changes in the applicability of the four main theories to research in related fields, the development of labour NGOs in China and even the promotion of migrant workers' rights in China. However, scholars 
of Chinese labour NGOs have rarely focused on confirming and challenging the relevant theories after 2017. This chapter reviews four significant theories in the research domain based on the assumption of the significant influence of policies which aim to weaken grassroots labour movements and Chinese labour NGOs. In line with the literature review, this study assumes that the applicability of the four major theories to explain and analyse grassroots labour movements in China has changed since 2017. Some aspects of the four theories will be more applicable, while others may no longer apply. These changes may also vary between Beijing, Tianjin and Yunnan Province. The study also needs to confirm this. 


\section{Chapter Three: Research Methodology}

The previous chapter clarifies the core research questions of this study. This research aims to investigate the goals and strategic choices of labour NGOs in Beijing, Tianjin and Yunnan Province, and identify the applicability of the four major social movement theories to the current situation. To that end, a qualitative research approach has been used.

This chapter begins by illustrating the most appropriate research philosophy for this study, followed by the advantages of the qualitative approach in testing the applicability of the four theories which I intend to examine. The benefits of in-depth case studies are also expounded. Next, I explain why I selected Beijing, Tianjin and Yunnan as the target regions of my fieldwork, and introduce the criteria and process of case selection. Finally, after clarifying the procedure for data collection and data analysis, I point out the potential ethical issues of the study and how they are resolved.

\subsection{Research Paradigm and Qualitative Approach}

The philosophical foundation of this study is a combination of interpretivism as the primary research paradigm and post-positivism as the secondary research paradigm. Specifically, this research has two objectives. One is to investigate what has changed in the goals and strategies of those labour NGOs operating in the three regions of mainland China after a series of policies introduced in 2017. This aims to investigate the objective reality of the current world. The other, foremost objective is to interpret how and why these changes to the goals and strategies were applied by Chinese labour NGOs. This is largely based on the interpretation of the perceptions and reactions of people involved in Chinese labour NGOs. Hence, post-positivism and interpretivism are used as separate research paradigms to achieve the twofold purpose.

Post-positivism is the most suitable philosophical paradigm for the first objective of the research. Like positivists, post-positivist researchers also affirm the role of evidence, 
logic and precision in empirical research. However, they further argue that the existence of realities, to some extent, cannot be directly observed. Instead, in many situations, a subsequent deduction is needed. Thus, it is often impossible to completely avoid the bias caused by the subjective consciousness of people in scientific research (Hanson, 1958; Popper, 1959; Kuhn, 2012).

Unlike the positivist quantitative approach to research, whose adherents show a preference for numerical data, post-positivists typically employ inductive forms of data collection, such as questionnaires or face-to-face interviews (Clark, 1998). Furthermore, while organisational goals and strategies, such as those of the labour NGOs investigated in this study, are more or less objective and exist outside of individual perceptions, they do not lend themselves to quantitative methods of formal hypothesis testing. However, since objective phenomena are not open to interpretation, neither is interpretivism a suitable research paradigm for this study. As a result, post-positivism is the most suitable research paradigm for the first objective of the research.

Interpretivism is used as the philosophical paradigm for the second objective of my research. In the social science domain, interpretivists believe that realities are multiple and diversified because they are shaped by the dynamic and complex society. That is, interpretivist scholars emphasise and interpret the context which shapes the reality (Sale, Lohfeld \& Brazil, 2002). Interpretivism also closely links researchers and their research respondents, and that linkage is an integral part of the scientific inquiry (Guba \& Lincoln, 1994; Denzin \& Lincoln, 2011). Interviews, as the most important research method of interpretivism, will inevitably produce interaction between researchers and interviewees that affects researchers' personal interpretation of the interviews. Realising it is impossible to completely avoid this linkage, interpretivism regards it as a part of empirical research.

The second objective of my research focuses on the causes and processes of the changes in the goals and strategies applied by Chinese labour NGOs, which are largely 
related to the special context of China. Neither positivism nor post-positivism is suited to explaining and analysing the context of a social phenomenon. From this perspective, interpretivism is the most appropriate philosophical paradigm to guide my study.

The selection of research approaches and research methods is largely determined by research questions (Clark, 1998; Tashakkori et al., 1998; Newman et al., 1998; Onwuegbuzie \& Leech, 2006). Because this research seeks to understand phenomena which are not easily quantifiable, the two philosophies applied in this research emphasise qualitative over quantitative analysis. Compared with the quantitative approach, the advantage of the qualitative research approach is that it can offer a more comprehensive and deeper insight into my research question (Lincoln \& Guba, 1985). Moreover, as Amaratunga et al. (2002) suggest, the purpose of the qualitative research approach is to explore, describe, interpret or analyse the social life of people.

Qualitative researchers generally follow an inductive logic process, which typically uses comparison and classification to get research results and further understand the world (Miles \& Huberman, 1984). Maxwell (2012) points out that a qualitative research approach is particularly appropriate for research which aims to understand the 'meaning' and contains subjective ideas from the perspective of research participants. It also contributes greatly to understanding the 'contexts' in which the objects of the research are embedded (p.17). Creswell (1994) also insists qualitative research is all about drawing a map by collecting individuals' perceptions and experience. Scholars who utilise a qualitative approach typically select a small-scale research target to closely observe or deeply investigate, maintain its characteristics during the data analysis and finally attempt to refine useful information to guide real life (Maxwell, 2012).

On account of this, the qualitative research approach is particularly suitable to answer my research question. On the one hand, it will assist me to deeply explore the possible factors that shape their goals and related strategies when Chinese labour NGOs represent rural migrant workers. On the other hand, it will help me test which theory(ies) 
or which aspect(s) of those four major theories can still be used to explain grassroots labour movements in China and which cannot.

\subsection{Strengths of Case Studies}

To explore the processes and underlying factors of changes in the goals and strategies of labour NGOs in China after 2017, case studies have been selected from the various qualitative methods as the research method in this study. According to Yin (2017), case studies focus on deeply exploring issues through a concern about single or multiple cases within a wide system or context. It is the most suitable research method when researchers attempt to study a person, situation, emerging phenomenon and the context involved in great depth. Case studies also allow the researcher to trace the emerging processes of a particular phenomenon as well as build the link between the research results obtained and the complex potential causes (George et al., 2005). In this regard, case studies contribute to answering my research question and achieve my research objectives.

In addition, a multiple case study method is used in this research. Compared with the single case method, multiple case studies may provide more valid research results as it may be more possible to generalised the research findings (Maxwell, 2012). To that end, I chose 10 cases to obtain reliable data and replicate research findings (Yin, 2013). Instead of conducting all the case studies at the same time, data collection was completed sequence. In sequential multiple case studies, the key points learnt from the previous case can be applied or validated in the next case (Yin, 2017). When conducting my research, this helped me adjust and revise my research strategies over time.

\subsection{Data Collection}

In this section, I illustrate the specific data collection process in my study. 


\subsubsection{Case Selection}

In this study, 10 labour NGOs in Beijing, Tianjin and Yunnan Province were selected as my target cases. Importantly, for researchers, the selection and evaluation of cases are determined not only by the research questions but also by the accessibility of cases. In this section, I explain my selection of fieldwork locations and cases.

Labour NGOs in Beijing, Tianjin and Yunnan are thought to be representative of developing grassroots labour movements across the whole of China. This is because, on the one hand, as illustrated in Figure 3.1 and Figure 3.2, the number of labour NGOs in the three regions are in the top range for the whole country (Beijing as the second, Tianjin and Yunnan as the seventh) according to the data of China Development Brief (2018).

Figure 3.1: Distribution of NGOs Providing Labour-Related Services in Mainland

\section{China (According to Province)}

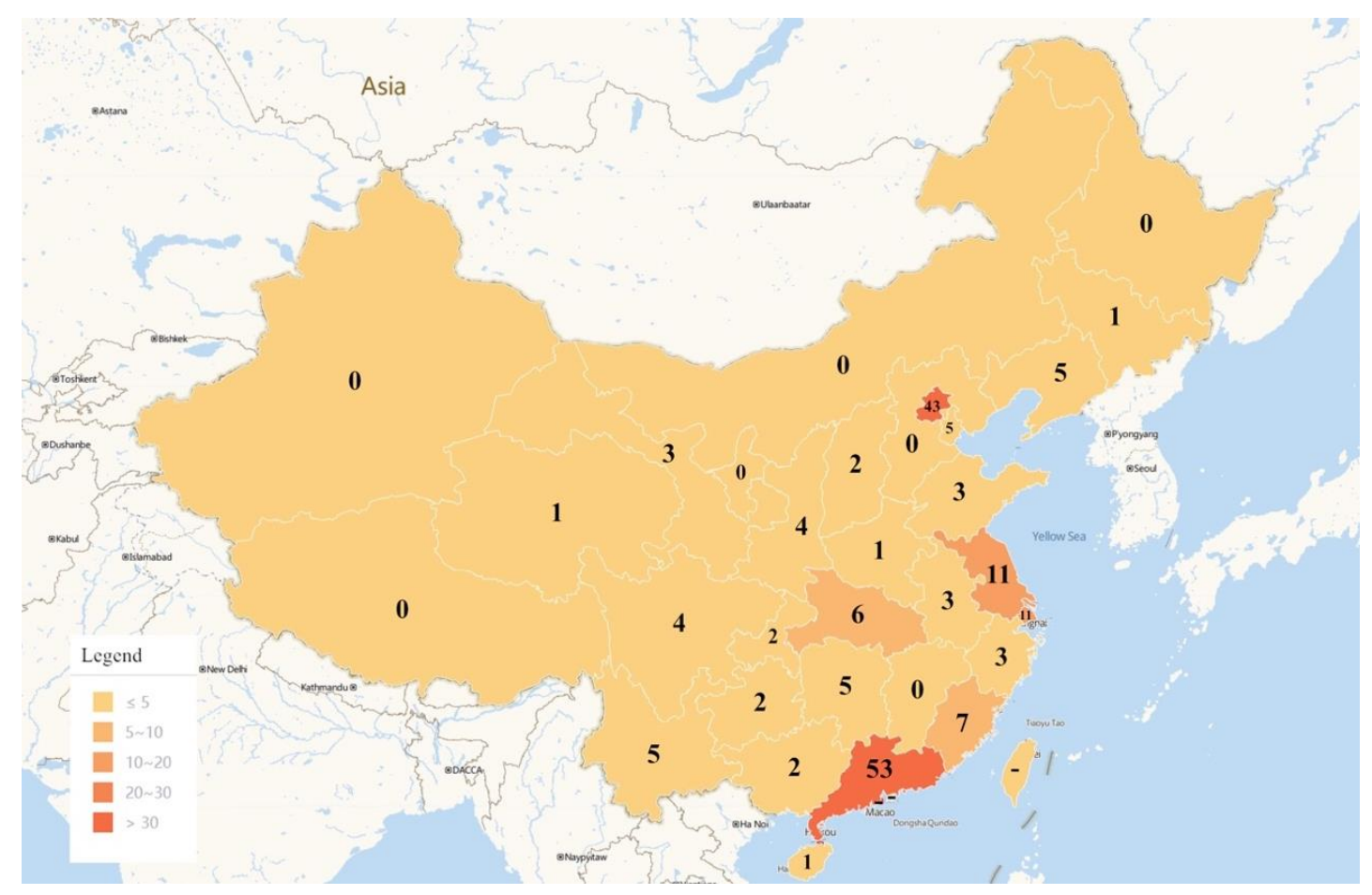

Source: China Development Brief, 2018 
Figure 3.2: Number of NGOs Providing Labour-Related Services in Beijing, Tianjin and Yunnan Province

\begin{tabular}{|c|c|c|c|}
\hline Region & Number of Labour NGOs & Percentage & Ranking \\
\hline Beijing & 43 & $23.50 \%$ & 2 \\
\hline Tianjin & 5 & $2.73 \%$ & 7 \\
\hline Yunnan Province & 5 & $2.73 \%$ & 7 \\
\hline Mainland China & 183 & $100 \%$ & - \\
\hline
\end{tabular}

Source: China Development Brief, 2018

On the other hand, selecting three different destinations for rural migrant workers allows geographic comparison of the goals and strategic choices of labour NGOs in this study. In particular, Beijing has always been one of the most popular destinations for rural migrant workers to reside and work (Xu, 2013). Therefore, it is very representative for my field study. Tianjin is geographically adjacent to Beijing, and the two cities share economic and cultural similarities. For these reasons, the two cities are administratively incorporated into the Beijing-Tianjin-Hebei region. In addition, Beijing and Tianjin are both municipalities, directly governed by the central government, and are among the most advanced in China in terms of economic development (see the GDP per capita shown in Figure 3.3). Finally, although for a shorter time than Beijing, Tianjin has been attracting a large number of migrants since the reform and opening up of China since 1978. Therefore, conducting a geographic comparison between labour NGOs in Beijing and Tianjin is helpful to test whether there are differences in the goals and strategic choices of these organisations when their level of cultural and economic development is similar.

Yunnan Province, located more than 2000km from Beijing and Tianjin in the southwest region, was also selected as one of the locations to conduct fieldwork. For one thing, Yunnan is significantly different from Beijing and Tianjin from an economic perspective. As illustrated in Figure 3.3, the GDP per capita index of Yunnan is far 
lower than in Beijing and Tianjin. Yunnan is also one of the least developed of the 31 provinces in mainland China. Moreover, because of the large geographical distance, the cultural gap between Yunnan and the other two destinations cannot be ignored. To this end, NGOs in Yunnan were also selected as cases for geographic comparison due to their significant economic and cultural differences.

Figure 3.3: GDP Per Capita of Beijing, Tianjin and Yunnan Province in 2018

\begin{tabular}{|c|c|c|}
\hline Region & $\begin{array}{c}\text { GDP per capita } \\
(\mathbf{C N Y})\end{array}$ & Ranking \\
\hline Beijing & 140,211 & 1 \\
\hline Tianjin & 120,711 & 3 \\
\hline Yunnan Province & 37,136 & 30 \\
\hline Average of mainland China & 64,500 & - \\
\hline
\end{tabular}

Source: NBSC, 2019

In order to further narrow the scope of case selection, and also because the aim of this research is to compare the differences in goals and strategies of labour NGOs before and after 2017, one selection criterion used was that the labour NGOs be registered and have provided actual labour services prior to 2017. In addition, to test the applicability of TAN theory, one of the four major social movement theories, the selected cases had to have functioned in cooperation with at least one overseas organisation or have received funds or other types of support from at least one foreign organisation. Finally, to increase the reliability and validity of the research results (Yin, 2013), each of the selected cases had to have a local reputation and influence.

However, staff working in Chinese labour NGOs have been wary of researchers from overseas institutions in recent years (Although I have Chinese nationality, the study was mostly completed and submitted in New Zealand). This makes it difficult for researchers who intend to conduct qualitative fieldwork in labour NGOs in China to get 
access to target cases. I was fortunate that two local researchers who focus on industrial relations in China provided contacts for these NGOs. I quickly approached these organisations and gained their consent to start my case studies. Accordingly, I identified the 10 labour NGOs not only because they all met my criteria for case selection but also because I was able to get access to them.

\subsubsection{Data Sources}

The data sources in this study primarily include the consultation of existing documents and the conduct of in-depth interviews. For existing documents, I looked up the internal documents through the official website of the labour NGOs to collect information such as their annual reports and development strategies. I also paid attention to external documents relating to the organisations like public databases, yearbooks from the local government and relevant laws or regulations. To improve research efficiency, this process was conducted in New Zealand before the research trip to China.

For the in-depth interviews, the data of my case studies came from 15 interviews with the 10 different labour NGOs conducted from October to December 2019 in China (See NGOs' list in Appendix 1). Among them, seven labour NGOs were in Beijing (B3 and B4 were banned from operating at the middle and beginning of 2019 respectively, so I interviewed their former staff in November 2019; the other five Beijing organisations are still operating normally), one in Tianjin and two in Yunnan Province. As Maxwell (2012) argues, the crucial criteria for selecting participants in research are whether they can answer the research question. The selection of interviewees in this study, therefore, involved searching for people who could best answer my research questions in my target organisations.

The purpose of this study is to examine the goals and strategies that Chinese labour NGOs currently adopt or have adopted in the past, and to investigate how and why these 
goals and strategies have changed over time. Therefore, the interviewees selected in this study are founders, managers or employees who have worked in the 10 labour NGOs for at least three years and are familiar with the development and operation of the organisation in great detail. All of the interview conversations were semi-structured (see Appendix 2 for the interview questionnaire and the Chinese translation), in that I provided a brief interview list with general questions, but there was flexibility to ask the interviewees more questions (Bernard, 2006). All the interviews were conducted face to face and lasted between 30 and 45 minutes. To accurately retain the research information, all the conversations were recorded with an electronic device. Since all the conversations were conducted in Chinese Mandarin, all interview recordings were translated into English after transcription.

\subsection{Data Analysis}

After the data collection phase, the data were transcribed, translated and then coded. Since only 15 interviews are included in this study, the analysis was done manually. The initial step of data analysis was classifying the interview responses into several meaningful categories. To that end, all the collected data were highlighted in different colours according to their frequency of repetition, then the codes were roughly catalogued as groups and described as different concepts. In the second stage, the codes were re-coded to check the reliability and the validity of the categories.

One of the most important objectives of this research is to identify the changes in goals and strategies applied by labour NGOs after the implementation of the Overseas NGOs Management Law in 2017. Therefore, the 10 NGOs studied were classified into three categories according to assumption about how their goals and strategies changed after 2017. As shown in Figure 3.4, the three categories are:

- $\quad$ NGOs with changed goals 
- NGOs with unchanged goals but changed strategies

- $\quad$ NGOs that maintained their goals and strategies

Figure 3.4: Assumptions about Changes to Labour NGOs' Goals and Strategies

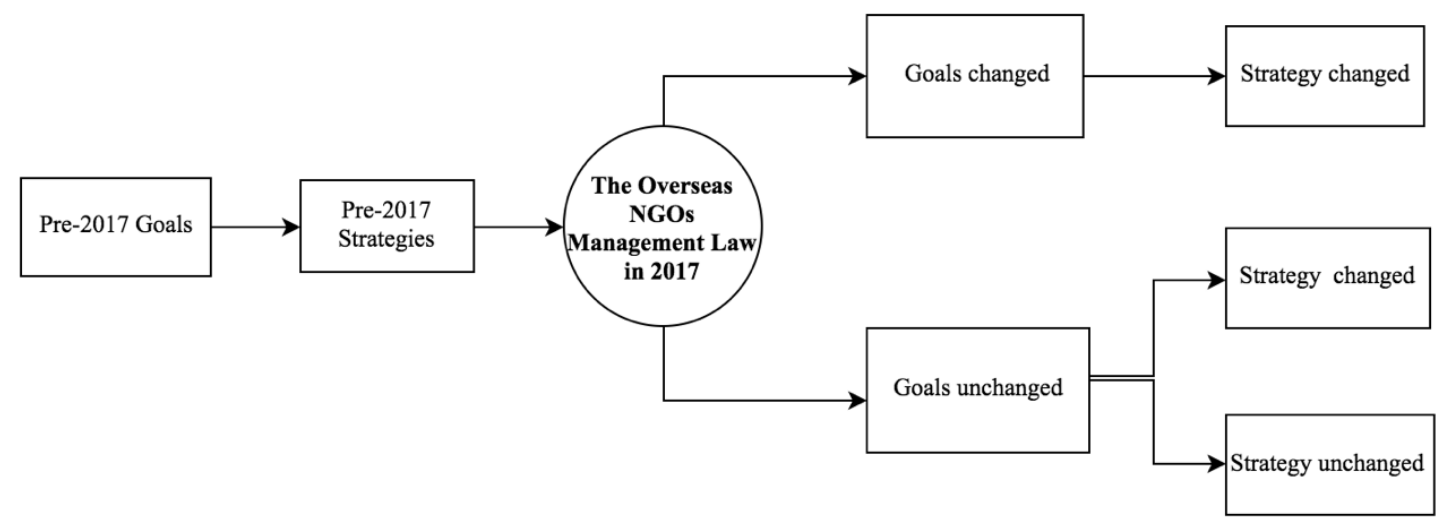

According to the interview responses, the goals applied by the labour NGOs studied were condensed into the three categories below:

- G1: guaranteeing the legal labour rights of workers;

- G2: integrating migrant workers into cities;

- G3: building a harmonious community for residents.

The strategies of those NGOs are shown as the following 10 categories. Notably, S1 to S6 are the six strategic activities of Chinese labour NGOs determined by previous studies (Chan, 2013; Xu, 2013; Franceschini \& Lin, 2019). S6 to S10 were refined from the interview responses in this study.

- S1: building up migrant workers' centres;

- $\quad$ S2: implementing outreach programmes on legal rights;

- S3: conducting policy advocacy through various social surveys;

- S4: facilitating collective bargaining;

- S5: militant collective labour mobilisation;

- S6: transforming into community service-based NGOs;

- $\quad$ S7: providing one-on-one legal representation in labour rights;

- $\quad$ S8: shifting focus away from migrant workers; 
- S9: expanding service target to also include other groups of workers;

- S10: establishing coalitions with other NGOs.

In addition, through data analysis, the causal factors affecting the goals and strategic choices of these NGOs are grouped into six categories as below:

- $\quad$ targeted government tolerance/repression;

- demographics of migrant workers associated with the NGOs;

- $\quad$ organisational size, structure and form of operation;

- the relationship between NGOs leadership and government;

- NGOs' exposure/concealment of their labour activities;

- $\quad$ NGOs' pre-2017 goals and strategies.

Finally, I re-evaluated the analysed data by repeatedly tracing and checking the completeness and accuracy between the data and my condensed categories. The factors affecting the goals and strategies of the 10 NGOs were analysed by comparing the responses of participants and checking for negative evidence. Results of the data analysis will be presented in the next chapter.

\subsection{Ethical Implications}

As Fuchs et al. (2019) argue, conducting qualitative research on labour-related issues in the context of China's authoritarianism carries high risks for both researchers and research participants. Hence, it was extremely important for this study to consider ethical issues, especially regarding the confidentiality of data. To that end, this research was approved by the Victoria University of Wellington Human Ethics Committee (Approval Number: 27984) before the data collection process. Specifically, to ensure that any risk to the researcher, labour NGOs participating in this research or interviewees remains low, in order to avoid the possibility that any conversation might be monitored or leaked, I avoided any telephone or video phone interviews in the process of data collection. All interviews were conducted on a one-to-one and face-to- 
face basis instead. All interviews were orally consented by the research participants after they read the research information (see Appendix 3 as the information sheet for research participant of this study). Furthermore, voice recordings, notes and other documentation produced at all stages of the research were properly uploaded and stored in university-assured cloud-based repositories only. This all took place in China before the researcher left the country. All relevant data were anonymised and remain confidential to the researcher only so that, due to security concerns, any information that might lead to the exposure of an individual's identity, including names and interview dates, has been avoided in any place in the thesis. Furthermore, all the data were transcribed and translated by the researcher only. Although I complement my data sources with public sources, organisational documents and other secondary literature, any sources that could compromise my interviewees' anonymity have been avoided. 


\section{Chapter Four: Research Findings}

This chapter presents the results of this study, including a comparison of the pre-2017 and post-2017 goals and strategies of the 10 labour NGOs studied. After the 2017 Overseas NGOs Management Law came into force, the NGOs' goals and strategies often changed - sometimes considerably - from those in the years leading up to that legislative change (see 'The pre-2017 and post-2017 Goals and Strategies of the 10 Labour NGOs' in Appendix 1).

These labour NGOs have been grouped into three clusters according to the effect of those changes on their choice of goals and/or strategies (see Figure 4.1). The first group (B5, Y2) contains those organisations which directly switched their labour-focused goals and transformed into community service-based NGOs. In the second group, B6, B7 and Y1 maintained their labour-focused goals, although their strategic focus became indirect, individualist and conservative. B1, B2 and T1 also moved away from their most radical strategies while keeping their goals that centred on migrant workers. The final group (B3, B4) barely changed their goals and strategies, maintaining all their direct, collective and radical labour goals and strategies after 2017. However, both NGOs in this group have been banned since 2019, perhaps highlighting the threat perceived by the other eight following enactment of the 2017 Overseas NGOs Management law. 
Figure 4.1: Pre-2017 and Post-2017 Goals and/or Strategic Choices of the Labour NGOs Studied

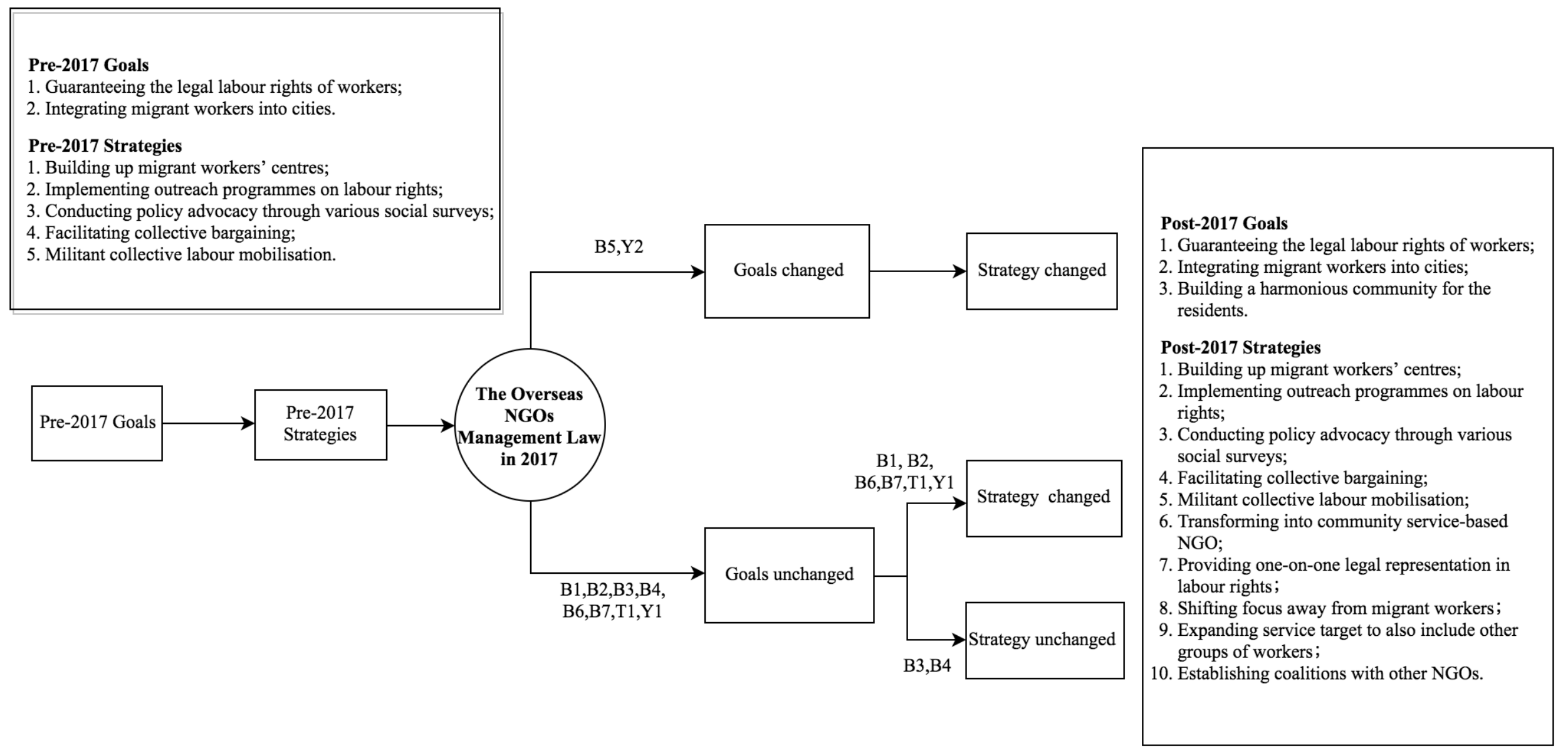




\subsection{NGOs with Changed Goals}

Having stopped providing any labour-focused services, B5 and Y2 became community service-based NGOs after 2017. Their goals and strategies were transformed from a labour-focused approach to a community-serving approach. This reflects a significant change, particularly for B5, which used to be one of the most influential labour NGOs in Beijing. Its primary goals before 2017 were helping migrant workers integrate into urban life and protecting their legal rights. To that end, from 2006, when the organisation was established, until 2017, it helped more than 160,000 migrant workers. Its major labour strategies before 2017 included building up workers' centres, which provided professional training, personal interest classes and legal consultation. It also engaged workers in outreach and consciousness-raising programmes, such as went to factories or workers' dormitories to distribute legal brochures and by established virtual workers' groups or networks through social media like WeChat and QQ for migrant workers. Facilitating collective bargaining was another notable strategy B5 previously employed. Its founder had studied in a university in Hong Kong with financial support from overseas institutions. He gained the experience and skills in collective bargaining from various labour movements in Hong Kong. That background led him to vigorously promote collective bargaining and support other collective actions to protect the legal rights of workers.

B5 employed these strategies to provide services to migrant workers in different Beijing industries. It initially focused on migrant workers who are employed informally and temporarily, such as housekeepers, who typically did not sign labour contracts with their employers and were not covered by social insurance. It also helped a large number of migrant construction workers during construction of the Beijing Olympic venues in 2008, for whom wage arrears and work injuries were particularly serious. After 2008, it moved its offices to a suburb of Beijing, where it started serving textile workers in small garment factories. 
After 2017, B5 completely abandoned its previous labour-focused goals and strategies. During my interview with the founder, he stated that it is currently a community-based social organisation with the goal of 'building a harmonious community for the residents'. The main activities of B5 also shifted to social work, community development and community governance. Examples include caring services for older people and children as well as community environmental governance.

Like B5, Y2 also provided traditional labour services to migrant workers before 2017. The founder of Y2 had worked in a labour NGO in Beijing for a long time before she moved to Yunnan Province. She was significantly influenced by her former organisation. Thus, she applied the same goals and strategies when she established the labour NGO in Yunnan in 2014. From 2014 to 2017, the major goals of Y2 included 'assisting migrant workers to integrate into cities' and 'protecting the legal rights of workers'. The main strategies it adopted to achieve these goals were establishing workers' centres where it conducted legal guidance training; Implemented outreach programmes on legal rights, such as built up workers' groups in factories to conduct special education of labour law, and promoted occupational and sexual protection information among female migrant workers; It also facilitated collective bargaining by, for instance, mobilising and organising migrant workers in the same factories to conduct collective bargaining, and providing assistance to workers in collective bargaining with employers.

However, after 2017, the founder of Y2 was determined to transform the NGO into a community-serving NGO. Hence, its office is now located in a high-grade residential community and aims to build up a harmonious community for the residents there. To achieve this goal, the services it provides cover a wide range of resident issues in that community such as environmental governance, caring for older people and children, and even caring for pets. 
The significant changes in goals and strategies of B5 and Y2 after 2017 are closely associated with their pre-2017 goals and strategies, the targeted government repression, the reduction in the number of migrant workers they serve, their small organisational size, the closer relationship between their leadership and government and the organisations' concealment of their labour actions. This will be discussed in the next chapter.

\subsection{NGOs with Unchanged Goals but Changed Strategies}

The second group, made up of six other labour NGOs (B1, B2, B6, B7, T1, Y1), have maintained their pre-2017 goals but now follow more indirect, individualist and conservative labour strategies. B6, B7 and Y1 are introduced first, because they completely shifted their focus to the four new labour strategies (i.e. 'providing one-onone legal representation in labour rights', 'shifting focus away from migrant workers', 'expanding service target to also include other groups of workers' and 'establishing coalitions with other NGOs') after 2017. Two of these NGOs (B6 and B7) are located in Beijing, while one (Y1) is located in Yunnan Province. The goals and strategies of $\mathrm{B} 1, \mathrm{~B} 2$ and $\mathrm{T} 1$ are presented later in this section as the changes in their strategic focuses are less obvious.

The office of B6 is located in a high-tech park on the outskirts of Beijing. Since its establishment in 2013, ensuring that the legal labour rights of migrant workers are protected and allowing migrant workers to integrate into cities have been its primary goals. Most of its initial labour services were provided for migrant workers engaged in electronics manufacturing. Before 2017, to ensure the legal rights of workers were protected, it carried out outreach and consciousness-raising programmes on labour rights. Distributing promotion materials and visiting workers' dormitories were its primary methods. It also conducted social surveys and discussed the results with 
relevant stakeholders, such as government and employers, to promote local policymaking.

After 2017, the strategies adopted by B6 changed a lot. Although the NGO still applies the two former strategies, it has increasingly paid more attention to conducting social surveys and policy advocacy and less to the outreach programmes on labour rights. This is not only because of government repression. The closer relationship between the founder of B6 and the government since 2017 has also led B6 to the conclusion that large-scale outreach programmes are less efficient. All its current outreach programmes are conducted online because most migrant workers B6 serves are Millennials for whom new technology is more acceptable.

Notably, B6 has applied three new strategies after 2017. The first strategy is providing one-on-one legal representation in labour rights. Influenced by targeted government repression after 2017, B6 conducts free individual lawyer consultations and representation for individual workers in labour disputes. This is also for the purpose of concealing its labour activities to reduce political risks and maintain its relationship with the government. For the same reason, the second strategy has been to shift its focus away from migrant workers. After 2017, B6 stopped most of its labour activities aimed at migrant workers and shifted its focus to the children of migrant workers and criminal workers who are sent to the community to serve their sentence. This strategic choice is also because the migrant workers B6 served moved away from individual migration to family migration in Beijing. The application of the third strategy is due to the reduction in the number of migrant workers associated with B6. The NGO has thus expanded its service target to include other groups of workers whose rights are violated, including local and migrant workers, white-collar and blue-collar workers.

B7 also maintained its pre-2017 goals but significantly switched its strategies towards a more indirect, individualist and conservative focus. The founder of B7 was 
previously a journalist who has encountered many migrant workers having difficulty surviving. These migrants can be credited with establishing Beijing as a cosmopolitan capital city, which they did while their labour rights were being violated and they were forced to live in virtual isolation outside the city. Hence, since its establishment in 2003, B7 has always been dedicated to guaranteeing the legal labour rights of workers while at the same time integrating migrant workers into the city.

Before 2017, B7 focused on directly providing services to young migrant workers in Beijing. Establishing a workers' centre was its first strategy. In the workers' centre, the NGO offered professional and legal training for migrant workers. Free legal consultation and legal representation by volunteer lawyers were also provided. A second strategy was implementing outreach and consciousness-raising programmes on labour rights. B7 visited a large number of construction sites and factories to distribute legal guidance materials. A third strategy it used before 2017 was conducting social surveys and policy advocacy. For instance, before 2005, employers in Beijing rarely purchased social insurance for migrant workers who were employed informally. In response, B7 surveyed migrant workers to determine their needs. Since one of B7's counsels was a deputy to the NPC (National People's Congress), B7 was easily able to discuss the results of their social surveys and reports about possible solutions with the authorities. As a result, a series of policies promoting social insurance payments were implemented in Beijing.

As a result of B7's advocacy, occupational disease prevention and treatment for migrant workers in Beijing have also improved. B7 used to serve migrant workers who worked in a factory in Beijing that manufactured tatami, a type of mat used as a flooring material in traditional Japanese-style rooms. Many workers in the factory got serious pneumoconiosis, a disease of the lungs caused by inhalation of dust. Through coordination with the media, experts, managers of the factory and government officials, B7 formulated a report on the prevention and treatment of pneumoconiosis. This report 
became the internal reference document for the regulations related to pneumoconiosis prevention issued by the State Council.

According to one staff member of B7,

'Our organisation has conducted a lot of research to promote policymaking for migrant workers over the years and had very good relations with scholars. Now almost every migrant worker in Beijing is covered by social insurance, and the occupational protection they receive at factories or construction sites is much better than before.'

The NGO made significant inroads into serving young migrant workers through its three pre-2017 strategies.

After 2017, although B7 retained its pre-2017 labour-focused goals, its strategies significantly changed. B7's three main strategies now are 'conducting policy advocacy through various social surveys', 'providing one-on-one legal representation in labour rights' and 'establishing coalitions with other NGOs'. B7 also still cooperates with scholars and the government, to change the working and living conditions of workers in urban areas through policymaking.

Compared with its former labour strategies, though, B7 has now reduced its activities aimed at collectivising workers. Due to targeted government repression and the need to conceal labour activities, providing one-on-one legal representation in labour rights for migrant workers and their families has become their primary strategy instead. Since it is one of the largest NGOs in Beijing, with extensive experience of serving migrant workers, B7 has also established coalitions with other NGOs by providing training services for them and volunteers. One of B7's major projects is to set up a social work school which trains those workers to learn professional social work skills and become volunteers or staff in other NGOs whose core business includes caring for children and older people, mental health counselling for youth, assistance to homeless people, and community environmental management. Through such a strategy, 
B7 has established a coalition with different NGOs over time. All the NGOs in this coalition share resources and make decisions together when relevant public events occur. This not only empowers the NGOs but also strengthens their voice in the policymaking process with the authorities in the face of the increasing repression after 2017.

Besides the three core strategies, there have been several notable changes in B7's strategies. According to the founder and two senior staff, the NGO has continued to engage workers in consciousness-raising outreach programmes on labour rights since 2017. However, unlike in the past, it is currently using online materials to attract migrant workers, partly because most of them are Millennials now. B7 has also expanded its service target to include other groups of workers, while shifting its focus away from migrant workers. The two strategies have been applied because of targeted government repression, a demographic change in the workers served by B7, the need to maintain a relationship with the government, and the NGO's decision to conceal its labour activities. After 2017, the organisation changed its service target by focusing on the whole migrant working population, including white-collar workers and the families of those migrants. In particular, it conducted many special projects for the children of migrant workers, many of whom moved away from rural to urban centres for the benefit of their children.

Y1 was founded by a famous scholar from Hong Kong at the beginning of the 2000s, and is the biggest labour NGO in Yunnan. The goals of the organisation are ensuring the legal labour rights of workers are upheld and integrating migrant workers into cities. Since its establishment, its goals have not changed, even following enactment of the 2017 Overseas NGOs Management law.

For a long time before 2017, Y1 applied the traditional labour strategies of Chinese labour NGOs. The organisation built up a workers' centre to provide legal 
representation and professional training. It also carried out consciousness-raising outreach programmes on labour rights, such as distributed informational materials about labour rights, both online and person-to-person. Conducting policy advocacy through various social surveys was another strategy it utilised before 2017. In particular, research undertaken by Y1 contributed to many local labour policies instituted in Yunnan.

Since 2017, although Y1 has maintained all three of its previous strategies, its focus has shifted significantly. Because of targeted government repression, it is currently paying more attention to policy advocacy than the other two previous strategies of 'building up workers' centres' and 'implementing outreach programmes on labour rights'. The manager of Y1 believes policy advocacy is the most effective strategy when representing migrant workers. Through policy advocacy, Y1 has been able to participate in the government's policy-making process and effect improvements in the working conditions of migrant workers. It has also helped the NGO to maintain a good relationship with the government and conceal direct labour activities.

For the same reason, instead of conducting collective action, Y1 started offering individual legal representation to migrant workers after 2017. Moreover, most of its target migrant workers have moved to the city with their families, the NGO has also shifted its strategic focus away from migrant workers only, and provides care and assistance for their children too. As one of the most influential and largest labour NGOs in Yunnan, Y1 has also established coalitions with other NGOs after 2017. Moreover, with Y1's support, many small NGOs have emerged. Y1 provides services for these NGOs, such as volunteer and social worker training. Although all of those NGOs operated independently, they share resources, as well as the political risks. 
B1, B2 and T1 maintained their pre-2017 labour-focused goals too, and altered their pre-2017 strategies relatively little following enactment of the Overseas NGOs Management law in 2017.

B1 was established more than 20 years ago, making it one of the oldest labour NGOs operating in mainland China. Guaranteeing the legal labour rights of migrant workers in urban areas has always been its primary goal, even after 2017. To achieve this goal, B1 has continued to apply a series of pre-2017 labour strategies. When it was founded, it established workers' centres and set up a legal aid hotline for migrant workers in Beijing. Many lawyers, scholars and people from all walks of life became volunteers. After receiving a call for help, B1 normally gathered workers who faced the same issues so that those volunteers could provide free legal consultation and representation. This legal aid hotline has helped a large number of migrant workers over the years. B1 also regularly conducted literature classes for migrant workers in the workers' centre. The founders of B1 thus published poems and prose about the stories of migrant workers. Another strategy the NGO used was to implement outreach programmes on labour rights. Like other typical Chinese labour NGOs, B1 regularly offered legal guidance and occupational safety protection tips in the migrant worker settlement community before 2017.

B1's post-2017 strategies have changed slightly. Specifically, the workers' centre it established currently only focuses on the legal aid hotline and online legal training instead of face-to-face activities. This is because Millennials now make up the majority of migrant workers B1 serves. Also, the new generation of migrant workers has different requirements for legal rights protection. Therefore, in terms of safeguarding those rights, the NGO has shifted its focus away from work injuries and wage arrears to working hours, working environment and working conditions. Due to staff shortages, it also set aside its pre-2017 strategy of 'implementing outreach programmes on labour rights' after 2017. Notably, while providing professional legal services, B1 has shifted 
to providing one-on-one labour rights legal representation. This is because, under the government's targeted repression since 2017, B1 also tends to conceal its labour activities to maintain its relationship with the authorities.

B2 has also maintained its pre-2017 goals while only making small changes to its strategies. B2 has been committed to helping migrant workers integrate into Beijing since the labour NGO was founded in 2002. This goal has not changed, even after 2017. Before 2017, setting up workers' centres and implementing outreach programmes on labour rights was its main strategies when representing migrant workers. To achieve the goal of integrating migrant workers into the city, the two founders established a centre in one migrant workers' settlement community in Beijing. They collected books and other related materials about how Chinese workers fight for their legal rights and built up a migrant workers' library, provided literature and music classes, and conducted free concerts and movies for workers in that centre. The founders of B2 held that cultural services were an effective way to help migrant workers integrate into urban life. They also distributed a series of materials like other labour NGOs to attract migrant workers to participate in their cultural activities. These materials normally contained legal guidance and occupational protection information as well. These cultural services attracted many sponsors. In light of media coverage of the NGO, many scholars, entrepreneurs, overseas foundations and celebrities donated funding to B2 before 2017 .

Since 2017, B2 has only maintained the strategy of building up workers' centres. The library remains open for workers and some entertainment activities are also provided. However, because of significant staff shortages and the need to conceal labour activities, all of the NGO's activities related to the implementation of outreach programmes on labour rights have been abandoned. 
$\mathrm{T} 1$ is the last labour NGO in this group. The founder of T1 was previously a migrant worker. After he received professional training, he joined a labour NGO in Beijing which served migrant workers. Several years later, he moved to Tianjin and set up T1. Protecting the legal labour rights of workers has always been its main goal, although its strategies have changed, albeit only slightly, since 2017.

When it was initially established, the founder of $\mathrm{T} 1$ attempted to combine entertainment activities with legal labour training for migrant workers in Tianjin. To that end, T1 established workers' centres and carried out consciousness-raising outreach programmes on labour rights as its main labour strategies. The workers' centres initially held events on labour topics and music classes for migrant workers. They also distributed legal materials to workers in the factories and construction sites as their primary outreach programmes on labour rights. After 2014, the founder of T1 found it was inefficient to help workers protect themselves by mainly relying on entertainment activities. He decided to apply more direct labour strategies as an alternative. T1 gradually shifted its focus from entertainment activities to legal services for migrant workers. Its workers' centre started to prioritise legal consultation and representation for migrant workers as the core strategy.

Since 2017, T1 has continued to apply its two pre-2017 strategies. However, to attract young migrant workers, when conducting outreach programmes on labour rights, T1 has replaced the physical distribution of legal guidance to workers with an official online site. Notably, it also has started to provide one-on-one legal representation in labour rights for migrant workers to reduce the potential political risks due to targeted government repression.

\subsection{NGOs that Maintained Their Goals and Strategies}


Among the 10 labour NGOs studied, B3 and B4 are the only two organisations which have adhered to all of their pre-2017 goals and strategies. Nevertheless, both were banned from operating in mid-2019 and early 2019, respectively.

Ensuring that 'the legal labour rights of workers are guaranteed' and 'integrating migrant workers into cities' were always the main goals of both B3 and B4. Unlike the traditional labour NGOs, B3 was an online media organisation which focused on labour-related issues in China. Its mission was to change public opinion towards migrant workers and help every migrant worker to be respected in cities. Specifically, the two NGOs aimed to enhance the 'voice' of these migrant workers, whose legal labour rights are violated and who are discriminated against in their urban setting.

To that end, from the time it was established, B3 ran an online labour magazine. 'Implementing outreach programmes on labour rights' and 'militant collective labour mobilisation' were the two main strategies B3 employed. The editorial staff of the magazine focused on mobilising public opinion in support of migrant workers around specific labour issues by conducting interviews with workers in trouble and providing commentaries. Topics of articles in the magazine changed dynamically according to current events. For instance, when the anti-sexual harassment movement 'Me Too', which originated in the US, became popular in China, B3 spent nearly six months focusing on the issue of sexual harassment of women in Chinese workplaces. While great concern was expressed in this regard for middle-class women, few people paid attention to sexual harassment of women working in factories and living at the bottom of society. The magazine's reporting was aimed, therefore, at conveying the stories of women working in the factories, which it did by interviewing these women.

The articles published in B3's magazine typically provided critical views on labour issues from different academic perspectives too. For example, on the topic of workplace sexual harassment of females, the articles not only refuted of gender inequality in the workplace but also analysed and criticised various viewpoints supporting feminism in 
the workplace. From its first edition, its editor-in-chief clearly defined the magazine's target audience as white-collar middle-class youth who were workers themselves although generally unaware of the needs of those at the bottom of the socio-economic scale.

Under increased repression of labour NGOs after 2017, B3's unique way of operating and its huge influence on mobilising public opinion directly led to it being banned in mid-2019.

B4 was established in 2013 by university students and scholars in a migrant worker community located in a Beijing suburb. The community is one of the biggest migrant worker settlements in Beijing and contains tens of thousands of construction workers. During its existence, the NGO helped migrant workers set up workers' groups and select leaders, many of whom later became its volunteers. I interviewed one of the workers that benefitted from this effort who, along with his parents, migrated to Beijing when he was in high school and has lived in the community served by B4. Supported by $\mathrm{B} 4$, the interviewee completed his university study and joined the NGO after graduating. He has lived in that community for more than 10 years and has in-depth knowledge with B4's operation.

B4's goals, integrating migrant workers in the community into urban life and ensuring that their legal labour rights are protected, never changed, nor did the various strategies it used in pursuit of those goals. First, it built up a workers' centre for its members, which ran music classes, occupational protection training relating to health and safety, and training in labour rights and advocacy. The second strategy B4 followed was implementing outreach programmes on labour rights which also included other migrant workers besides its members. Since the major residents of the community were construction workers, the staff of the NGO often went to the workers' dormitories to distribute brochures explaining their legal rights. They also went on site to ensure the 
working conditions, facilities and protective equipment for those workers met the legal requirements.

Work injuries, wages arrears, and the absence of employment contracts remained the most urgent labour issues for construction workers living in that community. Accordingly, B4 gathered workers who encountered similar problems, organised and trained them to conduct collective bargaining with their employers to fight for their legal rights. Other approaches it used included facilitating collective bargaining and mobilising militant collective labour activities. It is likely its efforts to continue engaging in these activities after 2017 drew it to the attention of the authorities, ultimately leading to the NGO being banned. Although insufficient project funding in early 2019 was also a factor, B4 ceased all operations after its founder was arrested by the police for 'causing public disorder' and other such acts. 


\section{Chapter Five: Discussion}

This chapter first analyses the six factors identified in this study which have directly affected the post-2017 goals and strategic choices of the 10 labour NGOs surveyed. They are 'targeted government tolerance/repression', 'demographics of migrant workers associated with the NGOs', 'organisational size, structure and form of operation', 'the relationship between NGO leadership and government', 'NGOs' exposure/concealment of their labour activities' and 'NGOs' pre-2017 goals and strategies'. It then analyses the effect of geographic location on the goals and strategic choices of NGOs in Beijing, Tianjin and Yunnan Province, although fails to confirm this as a significant factor. The interrelationship of the six causal factors is also presented at the end of the chapter.

\subsection{Targeted Government Tolerance/Repression}

Targeted government tolerance/repression towards grassroots labour organisations is one of the most fundamental factors affecting the post-2017 goals and strategic choices of the 10 labour NGOs surveyed. Since 2008, the authorities have attached great importance to protecting the rights and interests of workers due to the implementation of the Labor Contract Law, the Labor Dispute Mediation and Arbitration Law and the Social Insurance Law. Nevertheless, the rights of migrant workers continue to be violated in less regulated factories and construction sites. Thus, labour NGOs have continued to play an essential role in representing migrant workers in those less regulated workplaces. This is one of the most important reasons for government tolerance of the 10 labour NGOs before 2017. This is evident in four organisations (B1, B6, B7 and Y1) that were previously approved by the local government to provide legal aid to migrant workers. For instance, B1 was approved to establish the 'Labour Negotiation Committee' for migrant workers by the local civil affairs bureau. The successful establishment of B6 can be attributed to its undertaking of a government-led 
project to help migrant workers. Moreover, due to the Chinese government's tolerance, the 10 labour NGOs were all sponsored by foreign foundations, enterprises and governments before 2017. The pre-2017 goals and strategies of the 10 organisations were also more directly focused on migrant workers, more collective and more radical than their post-2017 goals and strategies.

After 2017, the government's attitude towards labour NGOs shifted from tolerance to repression. The Overseas NGOs Management Law implemented in 2017 restricts all their overseas financial sources. All legal aid approvals for those labour NGOs by local government have also been cancelled since 2017. To avoid increasing political risks, some NGOs have thus tended to change their strategies to more indirect, individualist and conservative strategies to conceal their labour actions and maintain their relationship with the government. B6, B7 and Y1 significantly shifted their strategic focus to four new post-2017 labour strategies. B1, B2 and T1 also applied 'providing one-on-one legal representation in labour rights' to fit the current political environment. Most importantly, B3 and B4 were the only two NGOs that maintained all their pre2017 goals and strategies after 2017, but both organisations were banned in 2019. This underscores the level of pressure exerted by the Chinese government on labour NGOs operating in the country following enactment of the 2017 Overseas NGOs Management Law and the extent to which the government has gone to enforce the legislation. It also suggests that, notwithstanding other factors that potentially may have influenced those shifts, the Overseas NGOs Management law is the primary reason the other 8 NGOs in this study have elected to change either their goals and/or their strategies after that legislation was passed.

In addition, the ACFTU attempted to intervene and replace the role of labour NGOs in representing migrant workers. Since 2017 , the ACFTU has increasingly paid more attention to the rights and interests of migrant workers around the country. For instance, it has started to promote the involvement of eight groups of workers in unions 
nationwide since 2019. These include truck drivers, couriers, carers, housekeepers, mall information workers, online food delivery workers, real estate agents and security guards. Most of these target workers are migrant workers. In this way, the ACFTU has attracted most members of B5 and Y2. This is one of the main reasons why the two NGOs have changed their goals and transformed from labour NGOs to NGOs serving the community.

Thus, targeted government tolerance/repression significantly influences the goals and strategic choices of the 10 labour NGOs studied. When the government showed tolerance towards labour NGOs before 2017, their goals and strategies were more direct, collective and radical. However, when the government's attitude became repressive after 2017, the goals and strategic choice of the 10 labour NGOs became more indirect, individualist and conservative.

This factor confirms the emphasis on the political environment and political opportunity in RM theory and PO theory. It is still applicable and even more obvious in explaining the goals and strategic choices of the 10 grassroots labour NGOs after 2017. Moreover, in the face of government repression after 2017, instead of continuing to depend on the social movement experience of western countries, the labour NGOs studied have paid more attention to exploring special labour movement approaches in the Chinese context. For example, B6, B7 and Y1 all employ strategies such as 'shifting focus away from migrant workers' and 'expanding service target to also include other groups of workers'. These strategies have all been developed by the target labour NGOs to fit the special context of China.

This also means a series of new strategies for grassroots labour movements has emerged in China. This meets the requirement of the first 'norms emerging' step of the 'inside-out' TAN theory proposed by Finnemore \& Sikkink (1998). Although these strategies applied by the target Chinese labour NGOs are not complete and sufficiently mature, they might be beneficial to similar labour movements in other non-democratic 
countries and regions, or labour movements in other contexts that experience similar policies aimed at weakening them.

The application of Stakeholder theory after 2017 may also need to be adjusted because the previous literature stressed the significance of the government and overseas sponsors as the most influential stakeholders for labour NGOs in China. However, based on analysis, the government plays a more essential role in explaining the goals and strategic choice of the target labour NGOs after 2017 while the role of overseas sponsors is less crucial. The related government departments in charge of the governance of labour NGOs in China have also changed. Along with the local civil affairs bureau and the police, government repression since 2017 has also shown the ACFTU to be another notable stakeholder of the labour NGOs studied. Since the intervene of the ACFTU, theses NGOs are experiencing a decline in the number of workers they represent.

\subsection{Demographics of Migrant Workers Associated with the NGOs}

Another fundamental factor is the demographics of migrant workers associated with the NGOs. This is independent of the Overseas NGOs Management Law in 2017 but has still significantly affected the goals and strategic choices of the NGOs both before and after 2017.

Specifically, some features of the demographics of migrant workers have undergone dramatic changes in recent years. The foremost change is a shift from individual migration to family migration. According to the founder of B7, over almost the last decade, many migrant workers it previously served have got married and raised children in the city. Many migrant workers have also moved to Beijing with their families in recent years. During this process, the needs of migrant workers have changed a lot. For individual migrant workers, the biggest issues were wage arrears or work injury. However, the need of workers migrating with their families, are far more 
complicated. Besides wage arrears and work injury, the education of children, juvenile delinquency and family relationships are also major challenges. Although it was not a focus of NGOs, B6, B7 and Y1 conducted a few activities for the children of migrant workers before 2017. After 2017, the three labour NGOs completely shifted their focus from individual migrant workers to migrant workers with families. The three organisations applied the strategy of 'shifting focus away from migrant workers' after 2017 with regard to problems like educations of minors and family care in the migrant workers' settlement communities they served. All the interviewees in the three NGOs maintained that the strategy not only meets the current needs of migrant workers but have also helped them avoid political risks since 2017.

Another feature is that most migrant workers associated with the NGOs in this study have changed from being the first generation of migrant workers to the second or even third generations. This means the main targets of these NGOs' service are Millennials. Due to progress with technology, the use of the internet and smartphone by those young workers is much higher than by older generations. For this reason, a number of these NGOs (B3, B4, B6, B7, T1 and Y1) have chosen to conduct outreach programmes on labour rights online since 2017. NGOs generally consider online activities a more effective method to distribute legal guidelines to young migrant workers. Moreover, the needs of those young migrant workers are different from the previous generation. They are more concerned about working hours, working environment and working conditions. Thus B1's legal aid and training service has changed from work injuries and wage arrears to those issues.

Moreover, the number of migrant workers served by these NGOs has decreased. According to the latest data from the National Bureau of Statistics of China (NBSC) in 2020, the growth rate of migrant workers has slowed down since 2018. To ease the pressure of the growing urban population, a policy encouraging migrant workers to return to their home town has been introduced, particularly in Beijing. After, a serious 
fire occurred in a migrant workers' settlement community at the end of 2017, the local government urgently evacuated all migrant workers in that community. Since then, the Beijing municipal government has stepped up efforts to encourage migrant workers to return to their home town. This has significantly influenced the goals and strategic choices of labour NGOs operating in Beijing. For example, B5's office was previously located in a migrant workers' settlement community. After 2017, however, most migrant workers in that community returned to their home town. As a result, B5 lost large number of service targets and employees, and the organisation quickly reduced in size. To survive, the founder of B5 took on contracts for the government's community service projects, a major reason for the NGO's transformation into a community service-based NGO. The founders of B6 and B7 also indicated that applying the strategy of 'expanding service target to also include other groups of workers' was partially due to the decreased number of migrant workers they served.

This factor negates the assumption in PO theory that political opportunity plays the only and decisive role in setting the goals and strategic choices of the labour NGOs studied. Instead it confirms that the demographics of migrant workers associated with the NGOs have also had a major influence. It also identifies migrant workers, in addition to the government, as a notable stakeholder of grassroots labour NGOs after 2017, as they have had a significant effect on the post-2017 goals and strategies adopted by the NGOs.

\subsection{Organisational Size, Structure and Form of Operation}

The various goals and strategic choices of the 10 labour NGOs studied have also been affected by their organisational size, structure and form of operation. Larger labour NGOs with a more well-developed structure had a greater possibility of choosing the four new post-2017 labour strategies: providing one-on-one legal representation in labour rights, shifting focus away from migrant workers, expanding service target to 
also include other groups of workers and establishing coalitions with other NGOs. These labour NGOs were more adept at forecasting and responding to policy changes. Therefore, they were more likely to adapt their goals and strategies to face the challenges created by the Overseas NGOs Management Law. For example, B6, B7 and Y1 were the three biggest organisations among the 10 labour NGOs. All three organisations employ more than 10 full-time staff while other labour NGOs only employ three to five on average. They are also better funded than other organisations studied. Before 2017, due to the strong social networks of the founders, the donations the three NGOs received from overseas were far greater than those received by the other organisations. Although the Overseas NGOs Management Law in 2017 limited their overseas funding, they successfully contracted for GPS projects and received even more financial support than before 2017.

Sufficient funding and human resources have enabled the three NGOs to develop policy evaluation and forecast departments within their organisations. B7, for example, hires many scholars to evaluate its policies. Y1 also has a policy forecasting department which contains many experts who have graduated from top universities all over the world, along with former government officials. The policy evaluation and forecast departments enable the three NGOs to navigate the current political minefield and avoid risks. In fact, they proposed the four new labour strategies as an alternative plan prior to the 2017 law. Therefore, the three NGOs immediately reacted to the 2017 policy change and adopted the four new strategies.

On the other hand, the other labour NGOs are smaller than B6, B7 and Y1. They all face long-term funding and staff shortage. The turnover rate of staff in B1, B2 and B4 has remained high since their establishment. My interviewees in B1 and B2 indicated that staff turnover in the two organisations annually is almost $40 \%$ to $50 \%$. Thus, the two NGOs abandoned their pre-2017 strategy of 'implementing outreach programmes on labour rights' as they needed more staff to carry it out. For B4, before the 
organisation was banned in 2017, most staff turnover was because of wage arrears and the repression of the authorities. The three NGOs are only able to continue daily operations rather than other activities such as policy forecasting. Hence, only small changes emerged in the goals and strategies of B1 and B2, and B4 maintained all its pre-2017 goals and strategies.

B3 and T1 have the most obvious staff shortages. Both organisations only employ three full-time staff and several volunteers. To increase its income, T1 set up a musical instrument shop after 2017. Thus, the staff needed to keep the shop operating at the same time as providing legal services to migrant workers. All evaluations of policy changes depended on the founder's experience learnt from the labour NGO he previously worked for in Beijing. According to B3's chief editor, to compete with other media, its magazine had to continue to update weekly, and the staff were only able to complete their daily work. Hence, little policy forecasting was done by the two organisations. This is also one of the reasons why T1 only slightly changed its strategies and B3 maintained all its goals and strategies after 2017. B5 and Y2 also faced similar funding and staff shortages, which had a direct impact on their decision to transform into community service-based NGOs.

The organisation's form of operation has also influenced the goals and strategic choices of some NGOs studied. For instance, as introduced in Chapter Four, B1 mainly provided its legal services to migrant workers through its legal aid hotline. This form of operation made it easier for B1 to shift to one-on-one legal services after 2017. This is because the legal aid hotline limits the number of legal service targets, B1 generally connected to only one migrant worker in each call. With the policy of weakening NGOs in 2017, B1 fully endorsed the strategy to provide one-on-one legal consultation in labour rights and representation rather than gathering workers together. B2 mainly focuses on providing cultural services to migrant workers. This form of organisation also impacts on its goals and strategic choices. 'Establishing workers' centres' is both 
the pre-2017 and post-2017 strategy of B2. Its primary activities in the workers' centres include setting up a library and conducting concerts for migrant workers. These activities help the NGO to avoid the political minefield. On the other hand, B3 operated as an online media organisation. This form of operation significantly increased the political risks the organisation faced due to its huge influence on public opinion about grassroots labour movements. It is one of the reasons B3 was banned in 2019.

Therefore, the organisational size, structure and form of operation of the labour NGOs studied also significantly impact on their goals and strategic choices. This confirms the emphasis on available resources in RM theory, which still plays an important role in the goals and strategic choices of labour NGOs. It also challenges PO theory, because, as well as political opportunity, organisational size, structure and form of operation play a crucial role in the goals and strategic choices of the grassroots labour NGOs in this study.

\subsection{Relationship between NGO Leadership and Government}

The relationship between the NGO leadership and government is also an essential factor influencing the goals and strategic choice of the Chinese labour NGOs studied. Before 2017, the leadership of B1, B2, B6, B7, T1 and Y1 all retained a close relationship with the government. As mentioned above, B1, B6, B7 and Y1 were approved by the government to provide legal services to migrant workers. B2 and T1 also cooperated with the local municipal government to conduct cultural activities for migrant workers. Because of this close relationship, the six NGOs were cautious about conducting collective action before 2017. On the other hand, the leadership of B3, B4, B5 and Y2 were in a distant relationship with the government before 2017. The four NGOs adopted the collective strategies of 'facilitating collective bargaining' and/or 'militant collective labour mobilisation' as the most effective strategies to represent migrant workers. 
This factor also influenced the post-2017 goals and strategic choices of the labour NGOs studied. Specifically, those labour NGOs with a closer relationship between their leadership and the government after 2017 were more likely to change their goals and strategies after the introduction of the Overseas NGOs Management Law, and vice versa. Half the organisations studied showed a close relationship with the government after 2017: B5, B6, B7, Y1 and Y2. In particular, B5 and Y2 were the only two NGOs whose relationship with the government became closer after 2017. The founder of B5 was selected as the current chairman of the local social organisation association in 2018. This association has more than 3000 member organisations and was built and managed directly by the authorities. The founder of Y2 was also selected as a member of the local standing committee of the CPPCC after 2017. At least one top manager in B6, B7 and Y1 served concurrently as a government official. For instance, more than three managers of $\mathrm{Y} 1$ are currently working in the local civil affairs bureau. Hence, the changes in the goals and strategic choices of the five NGOs are most obvious. As illustrated in the last chapter, B5 and Y2 directly changed their labour-focused goals and transformed into community service-based NGOs. B6, B7 and Y1 all shifted their strategic focuses to 'conducting policy advocacy through social surveys' and the four new post-2017 labour strategies.

There are two reasons why the close relationship between labour NGOs and the government has had such an impact on the goals and strategic choices of labour NGOs after 2017. Firstly, the close relationship changed the organisations' funding source. After the restriction on overseas sponsors in 2017, all five organisations received funding support from the authorities instead. They won GPS contracts to survive. According to the founder of B5, the projects normally provide substantial financial support which is 10 times or even 20 times higher than overseas sponsors donated. However, the requirements to apply for GPS projects are extremely strict. NGOs must show professional ability and experience in social work and also a close relationship between the leadership and the government. All five NGOs successfully bid for GPS 
projects. Besides, the policies after 2017 showed a trend to weaken grassroots labour organisations. GPS projects barely paid attention to issues affecting migrant workers. Many, for example, only supported community service-based NGOs. This directly led to the transformation of B5 and Y2 into community service-based NGOs. B6, B7 and Y1 chose to provide labour-focused services to migrant workers more indirectly to gain government funding.

Secondly, organisations whose leadership is in a closer relationship with the government normally have a greater acceptance of, and confidence in, the intervention of the ACFTU in labour issues related to migrant workers. The ACFTU's intervention directly led to changes in their goals and strategic choices since 2017. In particular, the founders of B5 and Y2 both believed that the official trade union would represent migrant workers better. The managers of B6, B7 and Y1 also became more confident about the effectiveness of the ACFTU's policies of after 2017.

After 2017, B1, B2 and T1 experienced a further distancing in the relationship between the organisations' leadership and the government. The government has cancelled B1's 'Labour Negotiation Committee' since 2017. The founders of B2 and T1 both indicated that the GPS projects severely limited NGOs' activities to help migrant workers. Therefore, after their overseas sponsors were restricted in 2017, none of the three organisations gained government funding. All of their incomes now rely on domestic donations from society and income from self-operating businesses. These NGOs learnt from the UK experience to start up 'Social Enterprise' which support NGOs' social benefit activities through profitable business activities. For instance, B2 operates a second-hand clothing market and orchards in the suburbs of Beijing. T1 sells and teaches instruments in its musical instruments shop to survive. As a result, the three organisations have all maintained their original labour-focused goals while only slightly changing their former labour strategies. 
The leadership of B3 and B4 had the most distant relationship with the government after 2017. B3's magazine had a huge influence on mobilising public opinion. After 2017, it continually posted articles on the internet. This weakened its relationship with the government and led to it being banned in 2019. As the interviewee in B4 indicated, its managers' discontent about the Overseas NGOs Management Law and anger about the unfair treatment of migrant workers increased. Thus, B4 stuck to all of its pre-2017 goals and strategies after 2017 and was forced to cease operation as well.

The relationship between the NGO leadership and government significantly influenced the goals and strategic choices of the labour NGOs studied. This factor confirms the emphases of RM theory on the political environment and leadership of SMOs, as both are still applicable to grassroots labour movements in Beijing, Tianjin and Yunnan even after 2017. PO theory also provides evidence to confirm the importance of political opportunity in grassroots labour movements. Nonetheless, according to analysis of the B4 example, grievances of the leadership can also affect an NGO's relationship with the authorities and finally influence its goals and strategic choices. This proves both RM and PO theory ignore the role of emotional factors in explaining the labour NGOs studied.

Regarding TAN theory, with the implementation of the Overseas NGOs Management Law, all 10 labour NGOs in the three different regions have had overseas financial support fully restricted. From this perspective, TAN theory has totally failed to explain the current situation of grassroots labour movements conducted by Chinese labour NGOs. However, the social enterprises of B2 and T1 also illustrate that some Chinese labour NGOs are still a part of the international labour advocacy network after 2017. The labour activities they have conducted follow the trend of current international events and other kinds of social movements, such as the transnational anti-sexual harassment movement 'Me Too' for working women that B3 conducted before the organisation was banned. These organisations still accept advocacy from overseas but 
have shifted from financial to methodological support. Thus, the application of TAN theory to grassroots labour NGOs needs to change accordingly to focus on the experience learnt from overseas. Finally, for Stakeholder theory, this factor re-confirms that the role of government as a stakeholder in Chinese labour NGOs studied has risen since 2017.

\subsection{NGOs' Exposure/Concealment of its Labour Activities}

NGOs' exposure/concealment of their labour activities is also another crucial factor to impact on the goals and strategic choices of the Chinese labour NGOs surveyed. Before 2017, most labour NGOs tended to expose their labour activities to the public. This helped the NGOs to attract donations from overseas. Almost all the 10 labour NGOs cooperated with the media closely before 2017. According to the interviewees, the more direct, collective and radical strategies applied during this period contributed to increasing the organisations' public influence and thus attracted more financial support from foreign foundations. Hence, the pre-2017 goals and strategic choices of the 10 NGOs were directly focused on migrant workers, and were also more collective and radical than the post-2017 strategies.

The post-2017 goals and strategic choices of these NGOs are also associated with their choices about exposure/concealment of their labour activities. Most NGOs studied have chosen to conceal their labour activities since the Overseas NGOs Management Law was implemented in 2017. NGOs cannot attract foreign funding by promoting their labour activities in the media any more. The law has also completely transformed the financial sources of B5, B6, B7, Y1 and Y2 from overseas sponsors to GPS projects. The five NGOs are thus regulated more strictly than other NGOs when it comes to mobilising public opinion. To conceal their labour activities, B5 and Y2 have become the community service-based NGOs. B6, B7 and Y1 also pay more attention to 
'providing one-on-one legal representation in labour rights', 'shifting focus away from migrant workers' and 'expanding service target to also include other groups of workers'.

Although they have had no financial support from the government since 2017, B1, B2 and T1 also conceal their labour activities as much as possible because of targeted government repression after 2017. To avoid the increasing political risks, B1 and T1 both employ 'providing one-on-one legal representation in labour rights' as their post2017 strategy to reduce collective action and its public influence. B1 and B2 have also abandoned the strategy of 'implementing outreach programmes on labour rights' to avoid the possibility of exposing their labour activities in public.

However, B3 and B4 were the only two organisations who continued to expose all their labour activities after 2017 and maintained all their pre-2017 goals and strategies. For B3 in particular, because it is an online media organisation, its labour activities had greater public influence than other traditional labour NGOs. According to its former chief editor, to ensure the quality of its articles, the NGO only employed editors who had graduated from top universities in the world. Consequently, B3 gradually became famous in Chinese social science circles and young white-collar workers' groups. B3's official accounts on more than 20 social media sites such as WeChat, Tencent and Sohu attracted a large number of subscribers. After 2017, the authorities' control of public opinion became extremely strict. B3 attempted to avoid any sensitive wording in their published articles. However, because of its mass audience, it was impossible to reduce its powerful public influence. This was the main reason behind its closure. B4 was also unable to conceal its labour actions significantly after 2017. The founders were scholars and students from several top universities in China. From the time of its establishment, B4 attracted public focus. Such public influence brought many donations for the organisation before 2017. Yet, the banning of B4 in 2019 was also partially the result of to its public influence. 
Accordingly, exposure/concealment of their labour activities significantly impact on both the pre-2017 and post-2017 goals and strategic choices of the 10 Chinese labour NGOs studied. This factor provides more evidence confirming the importance of NGOs' leadership which is highlighted by RM theory, because the choice to expose or conceal labour activities influences changes in their goals and strategies. It also identifies public opinion as another significant stakeholder that influences the goals and strategic choices of labour NGOs operating in the three different regions of China, although this is ignored by the previous literature which used Stakeholder theory to analyse Chinese grassroots labour NGOs.

\subsection{NGOs'Pre-2017 Goals and Strategies}

The last factor identified in this study is the pre-2017 goals and strategies of the labour NGOs studied. As the analysis above shows, the pre-2017 goals and strategies of these NGOs have also been affected by the five factors already discussed. Thus, this factor is not considered the most fundamental one affecting post-2017 goals and strategic choices.

The two pre-2017 collective strategies of 'facilitating collective bargaining' and 'militant collective labour mobilisation' significantly affected NGOs' choices after 2017. B5 and Y2, for example, both applied 'facilitating collective bargaining' as their main strategy before 2017. However, the two NGOs changed their pre-2017 goals and transformed into community service-based NGOs as a direct result of the Overseas NGOs Management Law in 2017. B3 and B4 were the only two of the 10 NGOs to apply the most radical strategy of 'militant collective labour mobilisation' before 2017. However, they have both been banned since 2019 because they maintained this radical strategy in the changed political climate.

As mentioned above, B6, B7 and Y1 were the only three NGOs that applied 'conducting policy advocacy through social surveys' as one of their pre-2017 strategies. 
The three organisations developed the ability to forecast and cope with policy changes when promoting policymaking by cooperating with the government. Hence, in response to Overseas NGOs Management Law in 2017, they all changed their strategic focuses to policy advocacy and the four emerging post-2017 labour strategies.

The post-2017 goals and strategic choices of B1, B2 and T1 were also influenced by their pre-2017 goals and strategies. Compared with the strategies of 'facilitating collective bargaining' and 'militant collective labour mobilisation', the pre-2017 strategies applied by these three NGOs were more conservative and carried less risk. This meant these NGOs only slightly changed their strategies after 2017 and maintained their goals.

Although these shifts were also influenced by the previous five factors, the pre-2017 goals and strategies of those NGOs directly influenced their choices after 2017. Therefore, NGOs' pre-2017 goals and strategies are also a notable causal factor that affected the post-2017 goals and strategic choices of the 10 labour NGOs. The identification of this factor highlights the role of organisational strategies in the development of SMOs, as emphasised by RM theory. This is also one aspect in which RM theory is applicable in explaining grassroots labour movements in Beijing, Tianjin and Yunnan.

\subsection{Geographic Location}

Another important factor this study has attempted to investigate is the impact of geographic location on the goals and strategic choices of labour NGOs after 2017. The research findings confirm that there are no significant differences in the post-2017 goals and strategic choices of the 10 labour NGOs according to different geographic locations. In other word, the trend of more indirect, individualist and conservative goals and strategies is evident in most labour NGOs in Beijing, Tianjin and Yunnan Province. The first reason for the trend emerging in all three regions is that the targeted 
government repression of NGOs happens in most parts of the country. According to the interviewees, almost all labour NGOs in China have attempted to change their goals and strategies to survive, including NGOs in the three regions. The changing demographic of migrant workers associated with the NGOs has also been a trend in the three regions. Workers associated with NGOs in the three places all prefer to migrate to cities with their families now. Most of them are Millennials and there are fewer than before. Accordingly, the 10 labour NGOs in the three regions have made similar adjustments to their goals and strategies.

Moreover, there may be other reasons for a similar trend to occur in NGOs in the three regions. For labour NGOs in Beijing, their goals and strategic changes may be due to greater political restriction because as the capital city, Beijing has a higher requirement to maintain safety and stability than any other cities in China. To reduce related risks, the local government has a lower tolerance for collective labour action. For instance, since 2017, the government has set up 'labour stations' in the community that B6 served. The stations aim to alert the authorities immediately labour disputes occur. This system ensures labour disputes are resolved before they expand to become collective action. This has contributed to the more indirect, individualist and conservative trend in goals and strategic choices of labour NGOs operating in Beijing since 2017.

However, the trend in Tianjin and Yunnan is not only due to the political environment. In fact, according to the founder of $\mathrm{T} 1$, there is more political space for labour NGOs in Tianjin to provide more radical labour services for migrant workers than in Beijing. However, labour NGOs in Tianjin emerged much later than those in Beijing and learnt many lessons from them. For example, the founder of T1 previously worked in a labour NGO in Beijing. T1's policymaking always follows labour NGOs in Beijing. For this reason, T1 adopts similar new trends to those NGOs. As in Tianjin, labour NGOs in Yunnan also emerged later, and thus learnt many lessons from 
organisations in other cities as well. The manager I interviewed in Y1, for example, previously worked in a famous international labour NGO in Guangzhou, and the founder of Y2 previously worked in a labour NGO in Beijing. Thus, after the implementation of the Overseas NGOs Management Law in 2017, they shifted their goals and strategies very quickly in line with NGOs in other cities.

Another reason for the same trend in Yunnan is the different method of settlement of its migrant workers. Most of the migrant workers in Beijing and Tianjin come from all over the country, and their home town is normally far from the two cities. Therefore, they prefer to live in collective dormitories on the construction sites or factories where they work. However, migrant workers in Kunming, the capital city of Yunnan Province, generally move within the province. Most of these migrant workers prefer to rent their own accommodation separately in the urban areas rather than live in the collective dormitories arranged by employers. Hence, the collective labour strategies applied by the labour NGOs in Beijing and Tianjin have been hard to apply in the context of Yunnan. For example, the founder of Y2 learnt a lot of lessons from her former NGO in Beijing. After establishing Y2, she used the same strategies, attempting to carry out a series of labour activities in the workers' dormitories. But she soon realised that many migrant workers do not even live in the same community. This was another important reason that led Y2 to transform into a community service-based NGO.

Hence, there is no evidence to support the premise that geographic location has significantly affected the goals and strategic choices of labour NGOs in the three different regions because they all adopted a similar trend to become more indirect, individualist and conservative. This also confirms that targeted government repression and the demographic change in migrant workers related to NGOs have been the most fundamental factors influencing the post-2017 goals and strategies of the 10 NGOs.

However, based on the analysis, political opportunity has had a relatively greater impact on the goals and strategic choices of those labour NGOs in Beijing than in 
Tianjin and Yunnan. On the other hand, the indirect, individualist and conservative trend also shown in organisations in Tianjin and Yunnan is a result of the empiricism of the NGOs' leadership and the different demographic structure of migrant workers in different regions. Therefore, the emphasis on the political environment and political opportunities in RM theory and PO theory is more prominent in Beijing than in Tianjin and Yunnan. 


\subsection{Interrelationship of the Factors}

Figure 5.1 illustrates the interrelationship between the six factors affecting the post2017 goals and/or strategic choices of the labour NGOs found in this research.

Figure 5.1: Interaction Between the Causal Factors Affecting the Post-2017 Goals $\underline{\text { and Strategies of Labour NGOs }}$

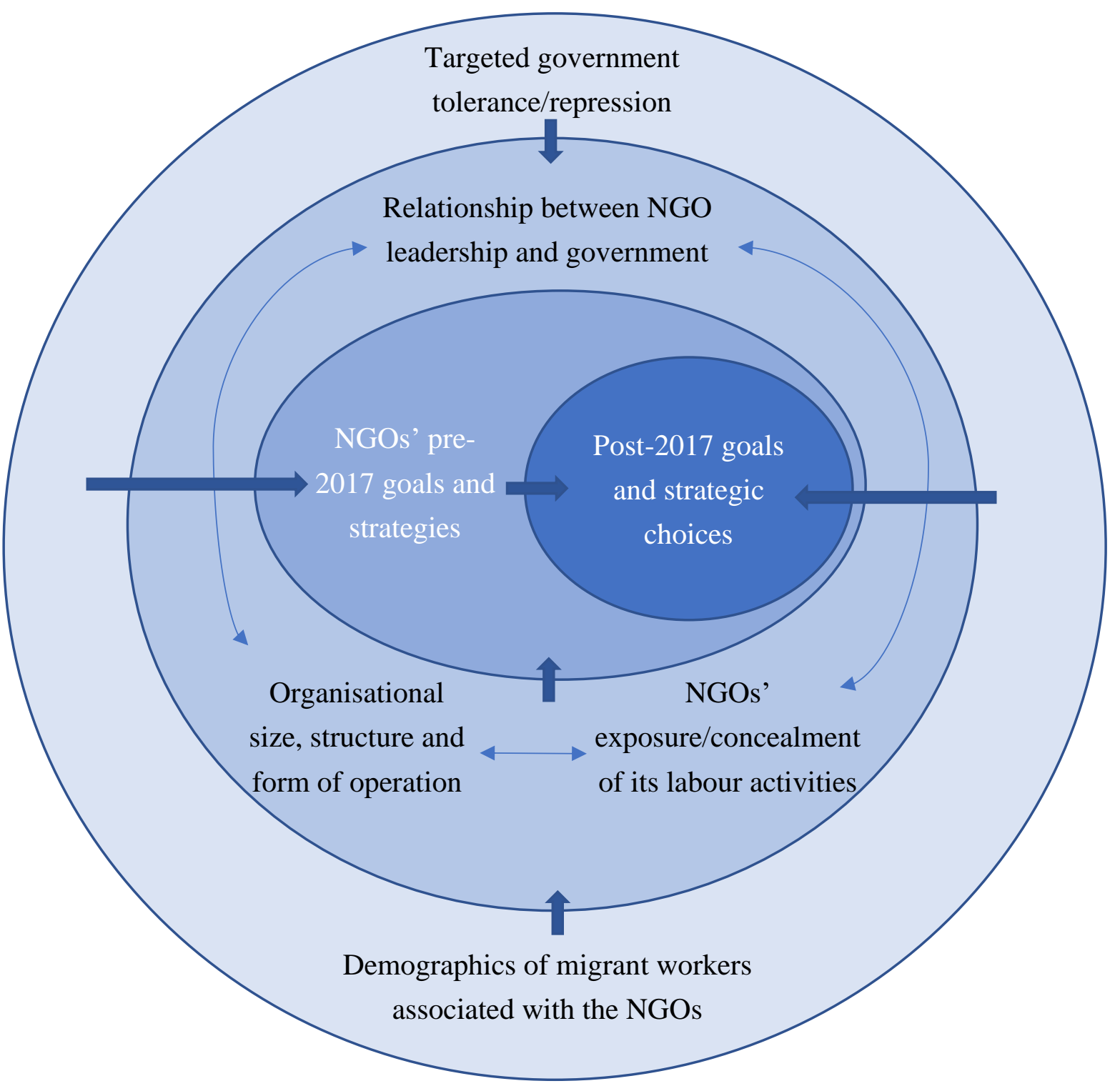


There are only two factors that are exogenous to the model: targeted government tolerance/repression and demographics of migrant workers associated with the NGOs. Those two factors influence three other factors: organisational size, structure and form of operation, the relationship between the NGO leadership and government, and NGO's exposure/concealment of its labour activities. Those three other factors, in turn, influence both pre-2017 and post-2017 goals and strategies, with the former also influencing the latter. Finally, degree of government tolerance and demographics of migrant workers also directly impact on the goals and strategic choices of the 10 NGOs. The previous sections analyse how degree of government tolerance, demographics, organisational dimensions, relationship with government and degree of exposure directly affect NGOs' goals and strategies, and the casual relationship between the pre2017 and the post-2017 goals and strategic choices. This section thus focuses on illustrating the interaction between the six causal factors.

Degree of government tolerance affects not only NGOs' goals and strategic choices but also organisational dimensions, relationship with government and degree of exposure. To be more specific, during the period of targeted government tolerance towards labour NGOs before 2017, some of the NGOs studied developed more easily and there was greater variety in their forms of operation (the B3's online labour media, for instance). However, government repression after 2017 led B3 to be banned, which shows less variety in NGOs' form of operations is allowed. Because of targeted government repression after 2017, the relationship between NGO leadership and the government also changed. B5 and Y2 became closer to the government while B3 and B4 became more distant from the authorities. Also, due to government tolerance before 2017, labour NGOs tended to expose more labour activities to attract financial support than after 2017.

The demographic of migrant workers associated with the NGOs is another significant casual factor which influenced NGOs' organisational dimensions, relationship with government, degree of exposure and goals and strategic choices in the 
figure. For instance, the decline in migrant workers associated with NGOs after 2017 also caused a change in their organisational size. Due to the reduction in service targets, half of the studied NGOs (B1, B2, B4, B5 and Y2) employed more staff before 2017 than now. In addition, because more workers sought help from NGOs before 2017, the government approved many NGOs to conduct legal services for migrant workers. These services have all been cancelled since 2017. To attract more workers and help them before 2017, these NGOs also exposed more labour activities in the media.

Moreover, NGOs' organisational dimensions, relationship with government and degree of exposure also interact with each other. The organisational size, structure and form of operation of a labour NGO partially influence the relationship between its leadership and the government. Whether before or after 2017, the government is more willing to cooperate with labour NGOs that are larger, more well-developed, and follow policies more closely. At the same time, the organisations' close or distant relationship with the government also affects the resources they can obtain, and thus affects the size, structure and form of operation of the NGOs. The size, structure, and form of operation of labour NGOs also impact on their exposure or concealment of labour activities (B3 and B4 are examples). Since they are more likely to be suppressed by the authorities, the NGOs that choose to expose more labour activities are often smaller than NGOs that conceal labour activities. Finally, labour NGOs with a close relationship with the government, such as B6, B7 and Y1, have tended to conceal their labour activities both before and after 2017. On the other hand, B3 and B4 always chose to expose their labour activities, whether before or after 2017, and their leadership had the worst relationship with the government among the 10 NGOs.

Hence, since targeted government tolerance/repression and demographics of migrant workers associated with the NGOs both significantly impact on all other factors, they are identified as the most fundamental factors affecting NGO's post-2017 goals and strategies. Because organisational size, structure and form of operation, the 
relationship between the NGO leadership and government, and NGO's exposure/concealment of its labour activities all affect NGOs' goals and strategic choices, they cannot be ignored either. Although the pre-2017 goals and strategies of labour NGOs is determined by all five factors above, it is also a direct causal factor that impact on their post-2017 goals and strategic choices. Finally, as shown by a geographic comparison, there are no significant differences in the post-2017 goals and strategic choices among the 10 labour NGOs in the three different regions in China in this study. 


\section{Chapter Six: Conclusion}

The first objective of this study is to explore the changes in goals and strategic choices of grassroots labour NGOs after the Overseas NGOs Management Law in 2017 and the underlying reasons. Research findings identify both the pre-2017 and the post-2017 goals and strategies of the 10 labour NGOs researched. These goals and strategies show a more indirect, individualist and conservative trend in general after 2017. These changes are attributed to six factors in the discussion. Finally, the different influences of these factors are determined.

The second, and the most essential, objective is to test the applicability of the four main social movement theories learnt from western countries in explaining the goals and strategic choices of the 10 Chinese labour NGOs operating in Beijing, Tianjin and Yunnan Province. The research findings and discussions show that, neither RM theory or PO theory can fully explain the goals and strategic choices of the labour NGOs studied in China, especially after 2017. The application of TAN theory and Stakeholder theory in discussing the goals and strategic choices of the Chinese labour NGOs studied has also significantly changed since 2017 . The applicability of each theory is defined as follows:

\subsection{Applicability of the Theories}

\section{Resource Mobilisation theory}

The findings and discussions of this research confirm that RM theory cannot fully explain the grassroots labour movements conducted by the target labour NGOs in Beijing, Tianjin and Yunnan. The aspect of RM theory that successfully explain grassroots labour movements of labour NGOs in the three target regions is its emphasis on resources, organisational strategies, leadership and the political environment. Analysis of geographic location shows the impact of the political environment is more obvious in Beijing than the other two regions. 
Nevertheless, two significant aspects of RM theory fail to explain the goals and strategic choices of the labour NGOs studied. First, most leaders of the labour NGOs in this research are not elites. Yet most of these NGOs have survived with limited resources after 2017. This proves that even NGOs with fewer resources can conduct grassroots labour movements. The second inappropriate aspect of the theory is that it fails to consider the role of emotional factors in a social movement. In this study, the grievances of the leadership of labour NGOs affect their relationship with the government and influence their goals and strategic choices. Thus, the influence of emotional elements in grassroots labour movements of labour NGOs in the three regions of China is another aspect that RM theory cannot explain.

\section{Political Opportunity theory}

PO theory effectively explains one of the main reasons for the sharp decline in the labour NGOs located in Beijing, Tianjin and Yunnan. However, because it only highlights the role of political opportunities, it cannot fully analyse grassroots labour movements in the current Chinese context. The aspect of PO theory that still applies is its emphasis on political opportunity which plays a more significant role in influencing the development of Chinese labour NGOs than it used to. However, the influence of political opportunity varies from region to region, as the comparison in this study above.

Although current labour policies are the tightest ever seen since the reform and opening up in 1978, labour NGOs have not disappeared. This is because Chinese migrant workers still need to be represented, both in terms of protection of their rights and integration into the city. Although the ACFTU is attempting to replace the role of labour NGOs in representing migrant workers, this is still in its infancy. Therefore, although political opportunities are the key factors that determine the development of the labour movement and labour NGOs, lack of political opportunities has not meant the disappearance of labour NGOs. Additionally, political opportunities are not the only factor to influence the changes in goals and strategic choices of Chinese labour NGOs. Based on the research findings, other factors like the demographic of migrant workers 
associated with the NGOs and their organisational size, structure and form of operation are also significantly associated with their goals and strategic choices. Thus, it is inappropriate to attribute all the reasons for the changes in goals and strategic choice of labour NGOs to lack of political opportunities.

\section{Transnational Advocacy Network theory}

This study challenges the application of TAN theory to goals and strategies of labour NGOs in Beijing, Tianjin and Yunnan. Although grassroots labour movements conducted by Chinese labour NGOs have had their overseas funds restricted since 2017, NGOs value overseas experience more than before. Hence, advocacy for financial support, which scholars generally focused on before 2017, is no longer applicable. When using TAN theory to discuss Chinese labour NGOs in the future, more attention should be paid to how NGOs learn from the methods and experience of transnational social movements. In addition, the current study suggests future grassroots labour movement activists and related research focus on how NGOs develop their own strategies in the specific context of China and initiate transnational advocacy.

\section{Stakeholder theory}

The present research also suggests the application of Stakeholder theory needs to change to explain grassroots labour movements conducted by labour NGOs in China. The government is still one of the most significant stakeholders in discussing the goals and strategic choices of the 10 labour NGOs studied. However, it is inappropriate to emphasis the role of overseas sponsors among the stakeholders as many scholars used to do. Within the government departments, the ACFTU should be also increasingly considered as a core stakeholder in future research and practice. In addition, previous scholars have ignored the significance of migrant workers. These workers are the most significant stakeholders to impact on labour NGOs in the context of China. Finally, other NGOs which cooperate with the target labour NGOs and public attention have 
also had a significant effect on the goals and strategic choices of labour NGOs since 2017.

\subsection{Contributions}

This study about the goals and strategies of labour NGOs operating in the three different Chinese regions makes both academic and practical contributions. From an academic perspective, many scholars have focused on the topic of Chinese labour NGOs, but few have paid attention to their goals and strategic choices. This research has thus filled a gap in studies on labour NGOs' goals and strategic choices. Notably, it discusses not only changes in goals and strategic choices of the studied labour NGOs but also the underlying reasons for those changes. This provides a new and more comprehensive perspective for future studies on Chinese labour NGOs.

There is no doubt that the implementation of the Overseas NGOs Management Law in 2017 significantly affected the development of labour NGOs in China. However, as political sensitivity about this topic has dramatically increased in China since 2017, fewer scholars have been able to get access to the target labour NGOs to conduct research. Hence, the impact of the 2017 law on their goals and strategic choices has been glossed over by researchers. This study helps to fill this gap because it explores the current development of the target labour NGOs in great depth. This provides an updated and in-depth insight into related research on this topic.

The final academic contribution of this research is to test the current applicability of the four main social movement theories in explaining the goals and strategic choices of labour NGOs in China. It challenges the applicability of the two most famous theories in this domain, RM theory and PO theory, to explain grassroots labour movements in the context of China. Both theories failed to be fully applicable to analyse the goals and strategic choices of the 10 labour NGOs in this study. It also clarifies that the focuses of TAN theory and Stakeholder theory need to change to fit the current goals and 
strategic choices of the target labour NGOs in China after 2017. This provides critical insight for future researchers when they attempt to use the four theories in studies about Chinese labour NGOs. At the same time, according to the research results, the application of the four theories may be different in different contexts. Therefore, future scholars of labour movements around the world need to apply these theories cautiously.

Practically, this research will help labour NGOs in China to develop future goals and strategies. It may also assist in developing the goals and strategic choices of unions and labour NGOs in other countries where labour organisations are becoming weaker. This study will also help migrant workers associated with the target labour NGOs. Policy making that affects labour NGOs by other stakeholders like the government and enterprises operating in China could also benefit from this research as well.

\subsection{Limitations}

Two major limitations in this thesis are worth noting. The first is that, although the researcher selected the 10 most representative labour NGOs in the three different regions in China as case studies, the results of this research cannot encompass the goals and strategic choices of all labour NGOs in the whole of mainland China. For example, the goals and strategic choices of labour NGOs in the Pearl River Delta may differ from other regions because extensive empirical research confirms that both the government's attitude (i.e. tolerance/repression) and the demographic of migrant workers associated with NGOs in the Pearl River Delta are distinct from other regions (Chan, 2018; Elfstrom, 2019; Spires et al., 2014). However, due to time limitations, resources and NGOs' accessibility, this study only selected the 10 most representative organisations in Beijing, Tianjin and Yunnan Province for in-depth case studies. Thus, the goals and strategies applied by labour NGOs in other regions may differ. In addition, factors influencing the goals and strategic choices of labour NGOs could be different in other regions of China. 
Factors other than the six causal factors confirmed in the research may also affect the post-2017 goals and strategic choices of the studied labour NGOs. This is another limitation of this study. Since all the target interviewees were founders, managers or staff in the 10 studied NGOs, all the data about the underlying factors affecting their goals and strategic choices focused only on NGOs' perspective. Therefore, other possible factors may have been overlooked. For instance, the interviewees did not mention other factors related to migrant workers besides their changed demographic such as support from associated migrant workers (Chan, 2018) and worker militancy (Elfstrom, 2019). The proportion of the workforce that supports NGOs' efforts may also influence their goals and strategic choices but this was barely mentioned by the 15 interviewees. Hence, I suggest future studies on factors affecting the goals and strategic choices of Chinese labour NGOs consider those factors as well.

\subsection{Suggestions for Future Studies}

In conclusion, due to policies designed to weaken labour NGOs in China, they are experiencing a huge decline, like the early trade unions in many western countries. However, even in this context, grassroots labour movements conducted by labour NGOs have not disappeared. On the contrary, the results of this study show that Chinese NGOs are adapting to the policy changes through various adjustments in their goals and strategic choices. In my final statement, I propose some questions and hope they can be reasonably answered by future research. These questions will help scholars and labour activists in this field to better explore and develop the possibilities for grassroots labour movements in China.

1. Which of the various goals and strategies adopted by labour NGOs are more effective and which are ineffective, and how can they be improved? 
2. Besides the factors identified in this study, are there any other possible factors affecting the goals and strategic choices of labour NGOs in China? What are these factors?

3. Social movement theories learned from the west all have certain limitations when applied in the context of China. Therefore, is it possible to develop a set of grassroots labour movement theories that are specifically suited to China to guide the development of labour NGOs? 


\section{References}

Aberle, D. F. (1966). The peyote religion among the Navaho. Viking Fund publications in anthropology.

Ackers, P., \& Payne, J. (1998). British trade unions and social partnership: Rhetoric, reality and strategy. International Journal of Human Resource Management, 9(3), 529-550.

Ahmed, S., Jaidka, K., \& Cho, J. (2017). Tweeting India's Nirbhaya protest: A study of emotional dynamics in an online social movement. Social Movement Studies, 16(4), $447-465$.

Alexander, P., \& Pfaffe, P. (2014). Social relationships to the means and ends of protest in South Africa's ongoing rebellion of the poor: The Balfour insurrections. Social Movement Studies, 13(2), 204-221.

Alhargan, R. A. (2012). The impact of the UN human rights system and human rights INGOs on the Saudi Government with special reference to the spiral model. The International Journal of Human Rights, 16(4), 598-623.

Alinsky, S. D. (1971). Rules for radicals: A pragmatic primer for realistic radicals.

Amaratunga, D., Baldry, D., Sarshar, M., \& Newton, R. (2002). Quantitative and qualitative research in the built environment: Application of "mixed" research approach. Work study, 51(1), 17-31. 
Arenas, D., Lozano, J. M., \& Albareda, L. (2009). The role of NGOs in CSR: Mutual perceptions among stakeholders. Journal of business ethics, 88(1), 175-197.

Baccaro, L., Hamann, K., \& Turner, L. (2003). The politics of labour movement revitalization: The need for a revitalized perspective. European Journal of Industrial Relations, 9(1), 119-133.

Bendell, J. (Ed.). (2017). Terms for endearment: Business, NGOs and sustainable development. Routledge.

Bernard, H. R. (2006). Interviewing: Unstructured and semistructured. Research methods in anthropology: Qualitative and quantitative approaches, 21.

Bevington, D., \& Dixon, C. (2005). Movement-relevant theory: Rethinking social movement scholarship and activism. Social movement studies, 4(3), 185-208.

Blumer, H. (1946). Elementary collective behavior. New Outline of the Principles of Sociology, 170-177.

Bryer, D., \& Magrath, J. (1999). New dimensions of global advocacy. Nonprofit and Voluntary Sector Quarterly, 28(1), 168-177.

Bryson, A., Ebbinghaus, B., \& Visser, J. (2011). Introduction: Causes, consequences and cures of union decline. European Journal of Industrial Relations, 17(2), 97-105. 
Bryson, J. M. (2004). What to do when stakeholders matter: Stakeholder identification and analysis techniques. Public management review, 6(1), 21-53.

Buechler, S. M. (1993). Beyond resource mobilization? Emerging trends in social movement theory. The Sociological Quarterly, 34(2), 217-235.

Buechler, S. M. (1995). New social movement theories. Sociological Quarterly, 36(3), 441464.

Chan, C. K. C. (2013). Community-based organizations for migrant workers' rights: The emergence of labour NGOs in China. Community Development Journal, 48(1), 6-22.

Chan, C. K. C., \& Hui, E. S. L. (2014). The development of collective bargaining in China: From collective bargaining by riot to party state-led wage bargaining. The China Quarterly., 221.

Chan, K. M., \& Zhou, Y. (2014). Political opportunity and the anti-dam movement in China: A case study of Nu River. In Social issues in China (pp. 311-330). Springer.

Charity Law of the People's Republic of China (2016). http://www.gov.cn/zhengce/2016-03/19/content 5055467.htm

Chen, F., \& Yang, X. (2017). Movement-oriented labour NGOs in South China: Exit with voice and displaced unionism. China Information, 31(2), 155-175. 
Cheng, J. Y. S., Ngok, K. L., \& Huang, Y. (2012). Multinational corporations, global civil society and Chinese labour: Workers' solidarity in China in the era of globalization. Economic and Industrial Democracy, 33(3), 379-401.

China Development Brief (2018). Chinese NGO List. http://www.chinadevelopmentbrief.org.cn/service/action/org_search.php?org_type=0\&fi eld_type $=1 \&$ area_type $=1 \&$ province_type $=0 \&$ city_type $=0 \&$ market_type $=0 \&$ keywords $=$

Clark, A. M. (1998). The qualitative-quantitative debate: Moving from positivism and confrontation to post-positivism and reconciliation. Journal of advanced nursing, 27(6), 1242-1249.

Clarkson, M. E. (1995). A stakeholder framework for analyzing and evaluating corporate social performance. Academy of management review, 20(1), 92-117.

Corduneanu-Huci, C., \& Osa, M. (2003). Running uphill: Political opportunity in nondemocracies. Comparative Sociology, 2(4), 605-629.

Creswell, J. W. (1994). Research design: Qualitative and quantitative approaches. Thousand Oaks, 88(2), 207.

Denzin, N. K., \& Lincoln, Y. S. (Eds.). (2011). The Sage handbook of qualitative research. Sage. 
Doh, J. P., \& Guay, T. R. (2006). Corporate social responsibility, public policy, and NGO activism in Europe and the United States: An institutional-stakeholder perspective. Journal of Management studies, 43(1), 47-73.

Domingo, P., \& O’Neil, T. (2014). The politics of legal empowerment. Legal mobilisation.

Durkheim, É., \& Karady, V. (1975). Textes: Religion, morale, anomie. Éditions de Minuit.

Ebbinghaus, B., \& Visser, J. (2000). Trade unions in Western Europe since 1945 (pp. 111126). Macmillan reference.

Eesley, C., \& Lenox, M. J. (2006). Firm responses to secondary stakeholder action. Strategic management journal, 27(8), 765-781.

Eisinger, P. K. (1973). The conditions of protest behavior in American cities. The American Political Science Review, 67(1), 11-28.

Elfstrom, M. (2019). A Tale of Two Deltas: Labour Politics in Jiangsu and Guangdong. British Journal of Industrial Relations, 57(2), 247-274.

Escobar, A. (2005). 24 Culture, economics, and politics in Latin American social movements: Theory and research. The global resistance reader, 299.

Ferree, M. M., \& Merrill, D. A. (2000). Hot movements, cold cognition: Thinking about social movements in gendered frames. Contemporary Sociology, 29(3), 454-462. 
Finnemore, M., \& Sikkink, K. (1998). International norm dynamics and political change. International organization, 887-917.

Fitzgerald, S., Chen, X., Qu, H., \& Sheff, M. G. (2013). Occupational injury among migrant workers in China: A systematic review. Injury prevention, 19(5), 348-354.

Fleay, C. (2006). Australian foreign policy, human rights in China and the spiral model. Australian Journal of Political Science, 41(1), 71-90.

Fonow, M. M., \& Franzway, S. (2007). Transnational union networks, feminism and labour advocacy. Trade Union Responses to Globalization: A Review by the Global Union Research Network. Geneva: ILO, 165-75.

Ford, M. (2006). Labour NGOs: An alternative form of labour organizing in Indonesia, 19911998. Asia Pacific Business Review, 12(2), 175-191.

Franceschini, I. (2014). Labour NGOs in China: a real force for political change?. The China Quarterly, 474-492.

Franceschini, I., \& Lin, K. (2019). Labour NGOs in China. From legal mobilisation to collective struggle (and back?) Sida Liu. China Perspectives, 2019(2019-1), 75-84.

Franceschini, I., \& Nesossi, E. (2018). State repression of Chinese labor NGOs: A chilling effect?. The China Journal, 80(1), 111-129. 
Freeman, R. E., \& Gilbert, D. R. (1987). Managing stakeholder interests. Business and society: Dimensions of conflict and cooperation, 379-422.

Friedman, A. L., \& Miles, S. (2002). Developing stakeholder theory. Journal of management studies, 39(1), 1-21.

Friedman, E. (2009). External pressure and local mobilization: Transnational activism and the emergence of the Chinese labor movement. Mobilization: An International Quarterly, 14(2), 199-218.

Friedman, E., \& Lee, C. K. (2010). Remaking the world of Chinese labour: A 30-year retrospective. British journal of industrial relations, 48(3), 507-533.

Fuchs, D., Fuk-Ying Tse, P., \& Feng, X. (2019). Labour research under coercive authoritarianism: Comparative reflections on fieldwork challenges in China. Economic and Industrial Democracy, 40(1), 132-155.

Gamson, W. A., \& Meyer, D. S. (1996). Framing political opportunity.

Ganz, M. (2005). Why David sometimes wins: Strategic capacity in social movements. The psychology of leadership: New perspectives and research, 209-238.

George, A. L., Bennett, A., Lynn-Jones, S. M., \& Miller, S. E. (2005). Case studies and theory development in the social sciences. mit Press. 
Giugni, M. (2011). Political opportunity: Still a useful concept?. In Contention and trust in cities and states (pp. 271-283). Springer, Dordrecht.

Gleiss, M. S. (2014). How Chinese labour NGOs legitimize their identity and voice. China Information, 28(3), 362-381.

Goodwin, J., \& Jasper, J. M. (1999). Caught in a winding, snarling vine: The structural bias of political process theory. In Sociological forum (Vol. 14, No. 1, pp. 27-54). Kluwer Academic Publishers-Plenum Publishers.

Goodwin, J., \& Jasper, J. M. (2004). Trouble in paradigms. Rethinking social movements: Structure, meaning, and emotion, 75-93.

Goodwin, J., Jasper, J., \& Polletta, F. (2000). The return of the repressed: The fall and rise of emotions in social movement theory. Mobilization: An International Quarterly, 5(1), 65-83.

Goodwin, J., Jasper, J. M., \& Polletta, F. (Eds.). (2009). Passionate politics: Emotions and social movements. University of Chicago Press.

Goodwin, J., \& Pfaff, S. (2001). Emotion work in high-risk social movements: Managing fear in the US and East German civil rights movements. Passionate politics: Emotions and social movements, $282-302$. 
Gould, D. B. (2004). Passionate political processes: Bringing emotions back into the study of social movements. Rethinking social movements: Structure, meaning, and emotion, 155176.

Guba, E. G., \& Lincoln, Y. S. (1994). Competing paradigms in qualitative research. Handbook of qualitative research, 2(163-194), 105.

Hancké, B. (1993). Trade union membership in Europe, 1960-1990: Rediscovering local unions. British Journal of Industrial Relations, 31(4), 593-613.

Hanson, N. R. (1958). Patterns of discovery: An inquiry into the conceptual foundations of science (Vol. 251). CUP Archive.

Harangozó, G., \& Zilahy, G. (2015). Cooperation between business and non-governmental organizations to promote sustainable development. Journal of Cleaner Production, 89, $18-31$.

Harrison, J. S., \& Freeman, R. E. (1999). Stakeholders, social responsibility, and performance: Empirical evidence and theoretical perspectives. Academy of management Journal, 42(5), 479-485.

He, A. J., \& Huang, G. (2015). Fighting for Migrant Labor Rights in the World's Factory: Legitimacy, resource constraints and strategies of grassroots migrant labor NGOs in South China. Journal of Contemporary China, 24(93), 471-492. 
Hsu, C., \& Teets, J. (2016). Is China's new overseas NGO management law sounding the death knell for civil society? Maybe not. The Asia-Pacific Journal, 14(4), 3.

Howell, J. (2015). Shall we dance? Welfarist incorporation and the politics of state-labour NGO relations. The China Quarterly, 223, 702-723.

Howell, J., \& Pringle, T. (2019). Shades of authoritarianism and state-labour relations in China. British Journal of Industrial Relations, 57(2), 223-246.

Hudson, A. (2001). NGOs' transnational advocacy networks: From 'legitimacy' to 'political responsibility'?. Global networks, 1(4), 331-352.

Jasper, J. M. (2008). The art of moral protest: Culture, biography, and creativity in social movements. University of Chicago Press.

Jenkins, J. C. (1983). Resource mobilization theory and the study of social movements. Annual review of sociology, 9(1), 527-553.

Jie, C. (2006). The NGO Community in China. Expanding linkages with transnational civil society and their democratic implications. China Perspectives, 2006(68), 29-40.

Keck, M. E., \& Sikkink, K. (1998). Activists beyond borders: Advocacy networks in international politics. Cornell University Press.

Keck, M. E., \& Sikkink, K. (1999). Transnational advocacy networks in international and regional politics. International social science journal, 51(159), 89-101. 
Kelly, J. (2012). Rethinking industrial relations: Mobilisation, collectivism and long waves. Routledge.

King, B. (2008). A social movement perspective of stakeholder collective action and influence. Business \& Society, 47(1), 21-49.

Kornhauser, W. (1959). The Politics of Mass. Society. New York/London.

Kuhn, T. S. (2012). The structure of scientific revolutions. University of Chicago press.

Labor Contract Law of the People's Republic of China (2008). http://www.gov.cn/flfg/2007-06/29/content_669394.htm

Labor Dispute Mediation and Arbitration Law of the People's Republic of China (2008). http://www.gov.cn/flfg/2007-12/29/content 847310.htm

Law of the People's Republic of China on Administration of Activities of Overseas Nongovernmental Organizations in the Mainland of China (2017). http://gat.hunan.gov.cn/articles/235/2019-3/58432.html

Lichtenstein, N. (2013). State of the Union: A Century of American Labor-Revised and Expanded Edition. Princeton University Press.

Lin, J. (2020). From Labor Unrest to Social Movement. In Chinese Politics and Labor Movements (pp. 53-81). Palgrave Macmillan, Cham.

Lincoln, Y. S., \& Guba, E.G. (1985). Naturalistic inquiry. Beverly Hills, CA: Sage Publications. 
Mancur Jr, O. (1968). The logic of collective action: Public goods and the theory of groups.

March, J. G., \& Olsen, J. P. (1989). Rediscovering Institutions: The Organisational Basis of Politics. Collier Macmillan Publishers.

Maxwell, J. A. (2012). Qualitative research design: An interactive approach (Vol. 41). Sage publications.

McAdam, D. (2010). Political process and the development of black insurgency, 1930-1970. University of Chicago Press.

McCarthy, J. D., \& Zald, M. N. (1973). The Trend of Social Movements in America: Professionalization and Resource Mobilization. Morristown, NJ: General Learning.

McCarthy, J. D., \& Zald, M. N. (1977). Resource mobilization and social movements: A partial theory. American journal of sociology, 82(6), 1212-1241.

McCarthy, J. D., \& Zald, M. N. (2001). The enduring vitality of the resource mobilization theory of social movements. In Handbook of sociological theory (pp. 533-565). Springer, Boston, MA.

Meyer, D. S. (2004). Protest and political opportunities. Annu. Rev. Sociol., 30, 125-145.

Meyer, D. S., \& Minkoff, D. C. (2004). Conceptualizing political opportunity. Social forces, 82(4), 1457-1492. 
Miles, M. B., \& Huberman, A. M. (1984). Qualitative data analysis: A sourcebook of new methods. In Qualitative data analysis: a sourcebook of new methods. Sage publications.

Missingham, B. (2003). Forging solidarity and identity in the assembly of the poor: From local struggles to a national social movement in Thailand. Asian Studies Review, 27(3), 317340.

Mitchell, R. K., Agle, B. R., \& Wood, D. J. (1997). Toward a theory of stakeholder identification and salience: Defining the principle of who and what really counts. Academy of management review, 22(4), 853-886.

Morris, A. (2000). Reflections on social movement theory: Criticisms and proposals. Contemporary Sociology, 29(3), 445-454.

Morris, A. D. (1986). The origins of the civil rights movement. Simon and Schuster.

Morris, A. D. (1999). A retrospective on the civil rights movement: Political and intellectual landmarks. Annual review of Sociology, 25(1), 517-539.

Morris, A. D., \& Mueller, C. M. (Eds.). (1992). Frontiers in social movement theory. Yale University Press.

Morton, K. (2005). The emergence of NGOs in China and their transnational linkages: Implications for domestic reform. Australian Journal of International Affairs, 59(4), 519-532. 
Murphy, D. F., \& Bendell, J. (1999). Partners in time? Business, NGOs and sustainable development.

NBSC (2019). Annual data by province.

http://data.stats.gov.cn/easyquery.htm?cn=E0103\&zb=A0201\&reg=110000\&sj=2018

NBSC (2020). Migrant Workers Monitoring Survey Report in 2019.

http://www.stats.gov.cn/tjsj/zxfb/202004/t20200430_1742724.html

Newman, I., Benz, C. R., \& Ridenour, C. S. (1998). Qualitative-quantitative research methodology: Exploring the interactive continuum. SIU Press.

Nilsen, A. G., \& Cox, L. (2013). 2. What Would a Marxist Theory of Social Movements Look Like?. In Marxism and social movements (pp. 63-81). Brill.

Oberschall, A. (1973). Social conflict and social movements. Prentice hall.

OECD (2018). Chapter 3. The role of collective bargaining systems in labour market performance. OECD Employment Outlook 2018.

Onwuegbuzie, A. J., \& Leech, N. L. (2006). Linking research questions to mixed methods data analysis procedures. The qualitative report, 11(3), 474-498.

Popper, K. R. (1959). The logic of scientific discovery. University Press.

Pringle, T. (2018). A solidarity machine? Hong Kong labour NGOs in Guangdong. Critical Sociology, 44(4-5), 661-675. 
Rawling, M. (2006). Australian trade unions as shareholder activists: The rocky path towards corporate democracy. Sydney L. Rev., 28, 227.

Risse, T. (1999). International norms and domestic change: Arguing and communicative behavior in the human rights area. Politics \& Society, 27(4), 529-559.

Risse-Kappen, T., Risse, T., Ropp, S. C., \& Sikkink, K. (Eds.). (1999). The power of human rights: International norms and domestic change (Vol. 66). Cambridge University Press.

Rowley, T. I., \& Moldoveanu, M. (2003). When will stakeholder groups act? An interest-and identity-based model of stakeholder group mobilization. Academy of management review, 28(2), 204-219.

Rucht, D. (1988). Themes, logics, and arenas of social movements: A structural approach. International Social Movement Research, 1(1), 305-328.

Ruiz-Junco, N. (2013). Feeling social movements: Theoretical contributions to social movement research on emotions. Sociology Compass, 7(1), 45-54.

Sage, G. H. (1999). Justice do it! The Nike transnational advocacy network: Organization, collective actions, and outcomes. Sociology of Sport Journal, 16(3), 206-235.

Sale, J. E., Lohfeld, L. H., \& Brazil, K. (2002). Revisiting the quantitative-qualitative debate: Implications for mixed-methods research. Quality and quantity, 36(1), 43-53. 
Santa Cruz, A. (2004). The Emergence of a Transnational Advocacy Network: International Election Monitoring in the Philippines, Chile, Nicaragua, and Mexico. PORTAL Journal of Multidisciplinary International Studies, 1(2).

Schroeder, M. (2008). The construction of China's climate politics: Transnational NGOs and the spiral model of international relations. Cambridge Review of International Affairs, 21(4), 505-525.

Shor, E. (2008). Conflict, terrorism, and the socialization of human rights norms: The spiral model revisited. Social Problems, 55(1), 117-138.

Social Insurance Law of the People's Republic of China (2011). http://www.gov.cn/flfg/2010-10/28/content_1732964.htm

Spires, A. J., Tao, L., \& Chan, K. M. (2014). Societal support for China's grass-roots NGOs: Evidence from Yunnan, Guangdong and Beijing. The China Journal, (71), 65-90.

Stein, L. V. (1848). Socialist and Communist Movements since the Third French Revolution.

Stern, P. C., Dietz, T., Abel, T., Guagnano, G. A., \& Kalof, L. (1999). A value-belief-norm theory of support for social movements: The case of environmentalism. Human ecology review, 81-97.

Tarrow, S. (1996). States and opportunities: The political structuring of social movements. Comparative perspectives on social movements: Political opportunities, mobilizing structures, and cultural framings, 90(2), 41-61. 
Tashakkori, A., Teddlie, C., \& Teddlie, C. B. (1998). Mixed methodology: Combining qualitative and quantitative approaches (Vol. 46). Sage.

Taylor, B., \& Li, Q. (2007). Is the ACFTU a union and does it matter?. Journal of Industrial Relations, 49(5), 701-715.

Taylor, V. (1999). Gender and social movements: Gender processes in women's self-help movements. Gender \& Society, 13(1), 8-33.

Tilly, C. (1977). From mobilization to revolution.

Wang, K. (2008). A changing arena of industrial relations in China. Employee Relations.

Wu, F. (2005). Double-mobilization: Transnational advocacy networks for China's environment and public health (Doctoral dissertation).

Xie, L., \& Van Der Heijden, H. A. (2010). Environmental movements and political opportunities: The case of China. Social movement studies, 9(1), 51-68.

Xu, Y. (2013). Labor non-governmental organizations in China: Mobilizing rural migrant workers. Journal of Industrial Relations, 55(2), 243-259.

Yang, G. (2005). Environmental NGOs and institutional dynamics in China. The China Quarterly, 181, 46-66.

Yin, R. K. (2013). Validity and generalization in future case study evaluations. Evaluation, 19(3), 321-332. 
Yin, R. K. (2017). Case study research and applications: Design and methods. Sage publications.

Zald, M. N., \& McCarthy, J. D. (Eds.). (1987). Social movements in an organizational society: Collected essays. Transaction Publishers.

Zhang, Z., \& Wu, X. (2017). Occupational segregation and earnings inequality: Rural migrants and local workers in urban China. Social science research, 61, 57-74. 


\section{Appendices}

Appendix 1

The Pre-2017 and Post-2017 Goals and Strategies of the 10 Labour NGOs

\begin{tabular}{|c|c|c|c|c|}
\hline Labour NGOs & $\begin{array}{c}\text { Goals before } \\
2017\end{array}$ & $\begin{array}{c}\text { Strategies } \\
\text { Before } 2017\end{array}$ & $\begin{array}{c}\text { Goals After } \\
2017\end{array}$ & $\begin{array}{c}\text { Strategies After } \\
2017\end{array}$ \\
\hline B1 & G1 & $\mathrm{S} 1, \mathrm{~S} 2$ & G1 & $\mathrm{S} 1, \mathrm{~S} 7$ \\
\hline B2 & G2 & $\mathrm{S} 1, \mathrm{~S} 2$ & G2 & S1 \\
\hline $\begin{array}{l}\text { B3 (Banned in } \\
\text { 2019) }\end{array}$ & $\mathrm{G} 1$ and $\mathrm{G} 2$ & $\mathrm{~S} 2, \mathrm{~S} 5$ & $\mathrm{G} 1$ and $\mathrm{G} 2$ & $\mathrm{~S} 2, \mathrm{~S} 5$ \\
\hline $\begin{array}{l}\text { B4 (Banned in } \\
\text { 2019) }\end{array}$ & $\mathrm{G} 1$ and $\mathrm{G} 2$ & $\begin{array}{l}\text { S1, S2, S4, } \\
\text { S5 }\end{array}$ & $\mathrm{G} 1$ and $\mathrm{G} 2$ & $\mathrm{~S} 1, \mathrm{~S} 2, \mathrm{~S} 4, \mathrm{~S} 5$ \\
\hline B5 & G1 and G2 & $\mathrm{S} 1, \mathrm{~S} 2, \mathrm{~S} 4$ & G3 & S6 \\
\hline B6 & $\mathrm{G} 1$ and $\mathrm{G} 2$ & $\mathrm{~S} 2, \mathrm{~S} 3$ & $\mathrm{G} 1$ and $\mathrm{G} 2$ & $\mathrm{~S} 2, \mathrm{~S} 3, \mathrm{~S} 7, \mathrm{~S} 8, \mathrm{~S} 9$ \\
\hline B7 & $\mathrm{G} 1$ and $\mathrm{G} 2$ & $\mathrm{~S} 1, \mathrm{~S} 2, \mathrm{~S} 3$ & $\mathrm{G} 1$ and $\mathrm{G} 2$ & $\begin{array}{l}\text { S2, S3, S7, S8, S9, } \\
\text { S10 }\end{array}$ \\
\hline $\mathrm{T} 1$ & G1 & $\mathrm{S} 1, \mathrm{~S} 2$ & G1 & $\mathrm{S} 1, \mathrm{~S} 2, \mathrm{~S} 7$ \\
\hline Y1 & $\mathrm{G} 1$ and $\mathrm{G} 2$ & $\mathrm{~S} 1, \mathrm{~S} 2, \mathrm{~S} 3$ & $\mathrm{G} 1$ and $\mathrm{G} 2$ & $\begin{array}{l}\text { S1, S2, S3, S7, S8, } \\
\text { S10 }\end{array}$ \\
\hline Y2 & $\mathrm{G} 1$ and $\mathrm{G} 2$ & $\mathrm{~S} 1, \mathrm{~S} 2, \mathrm{~S} 4$ & G3 & S6 \\
\hline
\end{tabular}

(G1: Guaranteeing the legal labour rights of workers; G2: Integrating migrant workers into cities; G3: Building a harmonious community for the residents. S1: Building up migrant workers' centres; S2: Implementing outreach programmes on labour rights; S3: Conducting policy advocacy through various social surveys; S4: Facilitating collective bargaining; S5: Militant collective labour mobilisation; S6: Transforming 
Appendices

into community service-based NGO; S7: Providing one-on-one legal representation in labour rights; S8: Shifting focus away from migrant workers; S9: Expanding service target to also include other groups of workers; S10: Establishing coalitions with other NGOs.) 
Appendix 2

\section{Semi-structured Interview Question List}

The Goals and Objectives

1. What are your goals and/or objectives in representing the urban-rural migrant workers in China?

Probing questions:

How would you describe successful achievement of those goals and/or objectives?

What does successful achievement of those goals and/or objectives look like?

What changes would have to occur for the NGO to conclude it had been successful in achieving those goals and/or objectives?

2. How, when and why have the NGOs goals and/objectives in representing rural migrant workers in China changed since the NGO first implemented operation in China?

Probing questions:

How has the status and influence of rural migrant workers in China changed since the NGO first implemented operation in China?

How has the role and influence of other stakeholders on NGO's strategic approach to representing rural migrant workers in China changed since the NGO first implemented operation in China?

3. What are the main dilemmas when you try to achieve the goals above?

Probing questions:

What barriers do Chinese labour NGOs face in achieving those goals and objectives?

How do Chinese labour NGOs attempt to overcome those barriers? 
The Strategies

4. To achieve the goals, what strategies are you currently applying? Are there any other alternative strategies?

Probing questions:

What strategies (plans) do Chinese labour NGOs currently apply to accomplish those goals and objectives?

Why do labour NGOs choose the current strategies?

5. How, when and why have the NGOs strategies in representing rural migrant workers in China changed since the NGO first implemented operation in China?

Evaluations

6. To what extent do you think the strategies achieve your objectives? And why? Probing questions:

How do those strategies align with the NGO's goals and objectives in representing rural migrant workers?

What barriers do Chinese labour NGOs face in implementing those strategies?

How do Chinese labour NGOs attempt to overcome those barriers? 


\section{Chinese Translation}

\section{半结构化访谈问题列表}

目标和目的

1. 您代表农民工的目的和/或目标是什么?

调查问题：

你如何描述这些目标和/或目的的成功实现?

这些目标和/或目标的成功实现是什么样的?

如果非政府组织认为他们已经成功地实现了这些目标和/或目标, 那么他们还需 要做出哪些改变?

2. 自非政府组织在中国成立以来, 非政府组织代表中国农民工的目标和目的是 何时、如何、为何发生变化的?

调查问题:

自 NGO 在中国成立以来，中国农民工的地位和影响发生了怎样的变化?

自非政府组织在中国开展业务以来, 其他利益相关者对非政府组织代表中国农

民工的战略途径的作用和影响发生了怎样的变化?

3. 当你试图达到上述目标时, 你面临的主要困境是什么?

调查问题:

中国劳工非政府组织在实现这些目标时面临哪些障碍?

中国的非政府劳工组织如何克服这些障碍?

\section{策略}

4. 为了实现这些目标, 你目前采用什么策略?还有其他的代替策略吗? 
调查问题:

中国劳工非政府组织目前采用哪些战略 (计划) 来实现这些目标?

为什么非政府组织选择当前的策略?

5. 自非政府组织在中国成立以来，非政府组织在中国代表农民工的策略发生了 怎样的变化? 以及, 这些变化是何时以及为何的变化?

\section{评估}

6. 你认为这些策略在多大程度上实现了你的目标?, 为什么?

调查问题：

这些战略是如何与非政府组织代表农民工的目标达成一致的?

中国的非政府劳工组织在实施这些战略时面临哪些障碍?

中国的非政府劳工组织如何克服这些障碍? 
Appendix 3

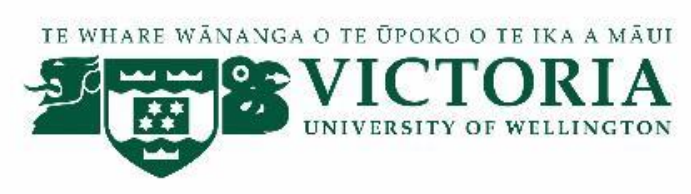

\section{Information Sheet for Research Participant}

You are invited to take part in this research. Please read this information before deciding whether or not to take part. If you decide to participate, thank you. If you decide not to participate, thank you for considering this request.

\section{Who am I?}

My name is Ao Zhou and I am a Masters student in Human Resource Management and Industrial Relations at Victoria University of Wellington. This research project is work towards my thesis.

\section{What is the aim of the project?}

This project aims to explore the goals and strategies currently employed by Chinese labour NGOs and analyse the reasons for the establishment of the specific goals and objectives and development of related strategies employed by Chinese labour NGOs in representing the interests of the rural migrant workers and advocating for the labour rights of these workers.

Your participation will support this research by involving in the interview with the researcher and providing information about the goal setting and strategy choosing of your organisation over time. This research has been approved by the Victoria University of Wellington Human Ethics Committee (Approval Number:27984).

\section{How can you help?}


You have been invited to participate because you are one of the important members of your labour NGOs. If you agree to take part I will interview you either in your office or in other public places you would like to choose. I will ask you questions about the goals and strategies of your organisation in representing rural-urban migrant workers during the past decade(s). The interview will take 30 to 45 minutes each. I will audio record the interview with your permission and write it up later. You can choose to not answer any question or stop the interview at any time, without giving a reason. You can withdraw from the study by contacting me at any time before 31/12/2019. If you withdraw, the information you provided will be destroyed or returned to you.

\section{What will happen to the information you give?}

This research is confidential*. This means that only the researcher will be aware of your identity but the research data will be combined and your identity will not be revealed in any reports, presentations, or public documentation. However, you should be aware that in small projects your identity might be obvious to others in your community.

Only I and my supervisor will read the notes or transcript of the interview. The interview transcripts, summaries and any recordings will be kept securely and destroyed on the end of my research (07/2020).

\section{What will the project produce?}

The information from my research will be used in my Master's thesis.

\section{If you accept this invitation, what are your rights as a research participant?}

\footnotetext{
* Confidentiality will be preserved except where you disclose something that causes me to be concerned about a risk of harm to yourself and/or others.
} 
You do not have to accept this invitation if you don't want to. If you do decide to participate, you have the right to:

- $\quad$ choose not to answer any question;

- $\quad$ ask for the recorder to be turned off at any time during the interview;

- $\quad$ withdraw from the study before $31 / 12 / 2019$;

- $\quad$ ask any questions about the study at any time;

- be able to read any reports of this research by emailing the researcher to request a copy.

\section{If you have any questions or problems, who can you contact?}

If you have any questions, either now or in the future, please feel free to contact either me or my supervisor:

\section{Student:}

Name: Ao Zhou

University email address:

zhouao2@myvuw.ac.nz

phone number:

18214174018

\section{Supervisor:}

Dr. Stephen Blumenfeld

Role: Director - Centre for Labour,

Employment and Work

School: School of Management

Phone: 044635706

stephen.blumenfeld@vuw.ac.nz

\section{Human Ethics Committee information}

If you have any concerns about the ethical conduct of the research you may contact the Victoria University HEC Convenor: Dr Judith Loveridge. Email hec@vuw.ac.nz or telephone +64-4-463 6028 . 


\section{Chinese Translation}

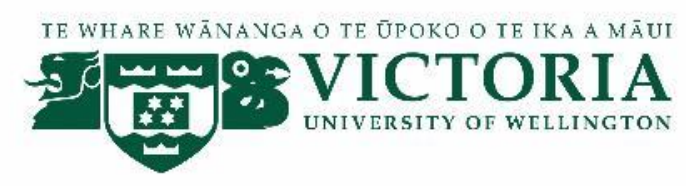

\section{研究参与者项目说明（中文译件）}

亲爱的项目参与者, 您好!

感谢您在百忙之中愿意受邀参加这项研究。在研究开始之前, 请您仔细阅读以 下信息，这大概将花费您 3 分钟的时间。

\section{关于我…....}

我叫周奥, 是惠灵顿维多利亚大学人力资源管理与劳资关系专业的在读硕士研 究生。这个研究项目的开展是为了完成我的硕士毕业论文。

\section{关于本研究……}

本项目旨在探讨当前中国劳工非政府组织在代表农民工群体时所采取的目标和 战略, 并探讨和分析这些具体的目标和战略建立的演变过程及原因, 以及它们 是如何在代表工人的利益, 主张工人的劳动权利方面发挥作用的。 您将通过参与与我的访谈, 提供有关您的组织的目标设定和策略选择的信息来 支持这项研究。本研究已获得新西兰惠灵顿维多利亚大学人类伦理委员会的批 准 (批准号:27984)。

\section{您将在本次研究中……}

您被邀请参加本项研究是因为贵组织是中国劳工非政府组织的重要成员之一。 如果您同意参加面试, 我将在您的办公室或其他您愿意选择的公共场所对你进 行面试。我将向你们提出有关你们组织在过去十年中代表工人的目标和战略的 问题。面试时间为 $30-45$ 分钟。我将在您允许的情况下录音采访, 并在稍后 
的研究工作中将其转化成文字。您可以在 2019 年 12 月 31 日前随时联系我退出 本次研究。如果您退出, 您所提供的资料将被销毁或退还给您。

\section{您提供的信息将会如何被呈现?}

这项研究是保密的。这意味着仅有我将知道您的身份, 研究数据将被合并, 并 且您的身份信息将不会在任何报告、演示或公开文档中被披露。但是，您应该 意识到, 在小型的研究项目中, 您的身份可能对同社区中的其他人很明显。 另外, 只有我和我的导师会阅读采访的笔记或文字记录。访谈记录、摘要和任 何录音将被妥善保存，并在我的研究结束时销毁 (预计 2020 年 7 月)。

\section{您作为研究参与者的权利是什么?}

・选择不回答任何问题；

- 要求在面试过程中随时关闭录音设备;

• 在 2019 年 12 月 31 日前退出本项研究;

・随时询问关于研究的任何问题;

-能够在项目结束后向研究人员要求一份这项研究的摘要报告。

\section{如果您有任何问题, 您可以联系谁?}

如果您现在或将来有任何问题, 请随时联系我或我的导师: 
学生:

周奥

邮箱：zhouao2@myvuw.ac.nz

\section{电话号码：}

18214174018

\section{导师：}

Stephen Blumenfeld 博士

职位：惠灵顿维多利亚大学劳

动, 雇佣和工作研究中心主管

电话： 044635706

\section{邮箱:}

stephen. blumenfeld@vuw. ac.nz

*如您对研究的道德操守有任何疑问, 请联络维多利亚大学人类伦理委员会负责人:

Judith Loveridge 博士。电子邮件: hec@vuw. ac 电话: +64-4-463 6028。 